\title{
Who Disciplines Bank Managers?
}

\author{
Martin Čihák, Andrea Maechler, \\ Klaus Schaeck, and Stéphanie Stolz
}




\title{
IMF Working Paper
}

\section{Who Disciplines Bank Managers?}

\section{Prepared by Martin Čihák, Andrea Maechler, Klaus Schaeck, Stéphanie Stolz ${ }^{1}$}

Authorized for distribution by Dimitri G. Demekas

December 2009

\begin{abstract}
This Working Paper should not be reported as representing the views of the IMF. The views expressed in this Working Paper are those of the author(s) and do not necessarily represent those of the IMF or IMF policy. Working Papers describe research in progress by the author(s) and are published to elicit comments and to further debate.

We bring to bear a hand-collected dataset of executive turnovers in U.S. banks to test the efficacy of market discipline in a 'laboratory setting' by analyzing banks that are less likely to be subject to government support. Specifically, we focus on a new face of market discipline: stakeholders' ability to fire an executive. Using conditional logit regressions to examine the roles of debtholders, shareholders, and regulators in removing executives, we present novel evidence that executives are more likely to be dismissed if their bank is risky, incurs losses, cuts dividends, has a high charter value, and holds high levels of subordinated debt. We only find limited evidence that forced turnovers improve bank performance.
\end{abstract}

JEL Classification Numbers: $\quad$ C41, G21, G28, L11

Keywords: Market discipline, executive turnover, financial soundness, corporate governance Authors’ E-Mail Addresses: mcihak@imf.org, amaechler@imf.org, klaus.schaeck@bangor.ac.uk, stephanie.stolz@ecb.int

\footnotetext{
${ }^{1}$ This project was initiated while Klaus Schaeck was a visiting scholar at the IMF. We thank the late Mark Swinburne for guidance, and to Robert Bliss, Paul Kupiec, Haluk Unal, Bob DeYoung, Erlend Nier, James Vickery, Lamont Black, Hesna Genay, Greg Nini, Larry Wall, Rich Rosen, Fred van Raij, Aleksandra Gregoric, Nicolas Blancher, Daniel Hardy, Andrea Sironi, Giuliano Iannotta, Enrico Onali, Phil Molyneux, Elizabeth Webb, Dimitri Demekas, seminar participants at the FDIC, IMF, ECB, Bank of England, Federal Reserve Bank of San Francisco, Deutsche Bundesbank, Bangor Business School, and participants at the $45^{\text {th }}$ Bank Market Structure Conference at the Federal Reserve Bank of Chicago, at the Financial Intermediation Research Society Meeting, Prague, at the Financial Stability Conference at Tilburg University, at the $4{ }^{\text {th }}$ FinLawMetrics Conference at Bocconi University, at the Corporate Governance Conference at Copenhagen Business School, at the CAREFIN Conference at Bocconi University, and at the FMA Conference in Reno for helpful comments. Ken Jones and Robert Grohal offered insights into the data on FDIC enforcement actions. Watcharee Corkill and Thanh Van Nguyen provided outstanding research assistance, and Graham Colin-Jones gave us useful editorial suggestions.
} 


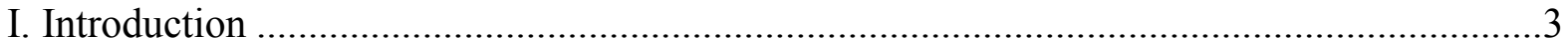

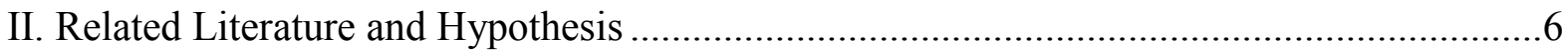

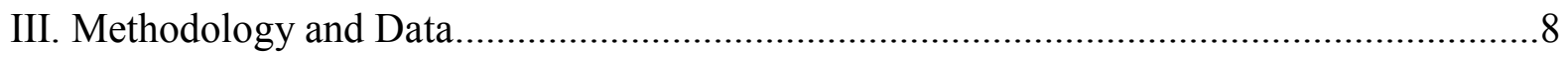

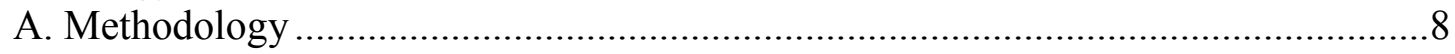

B. Variable Selection ................................................................................. 9

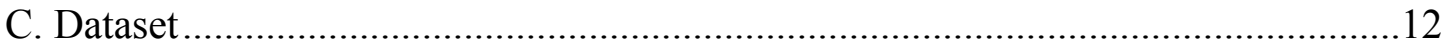

IV. Bank Performance Prior to Executive Turnover ......................................................17

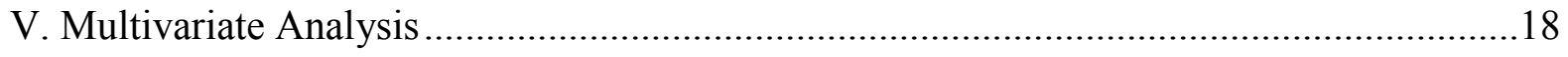

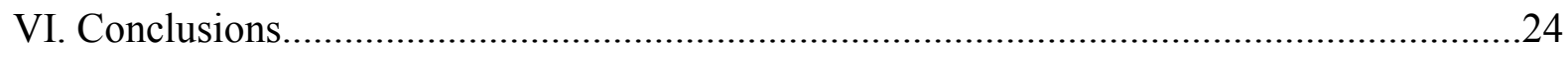

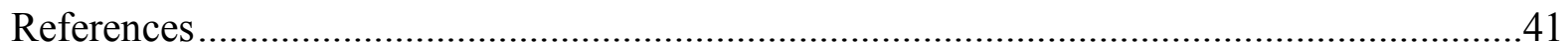

Figure

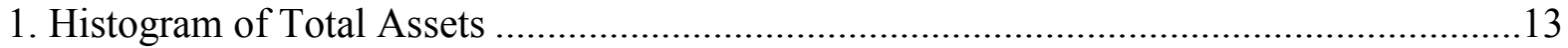

Tables

1. Descriptive Statistics, Differences of Means and Medians, and Correlations ....................26

2. Percentage Changes in Bank Performance Prior to Executive Turnover ..........................28

3. Conditional Logit Models for Different Sources of Discipine ........................................29

4. Key Variables of Interest by Percentile of Z-Score .......................................................30

5. Changes in Bank Performance After Executive Turnovers (Treatment Group).................31

6. Changes in Bank Performance After Executive Turnovers (Treatment and Control Group)32

7. Changes in Bank Performance After Executive Turnovers (Matching on Propensity Scores,

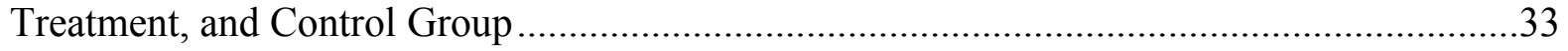

Appendices

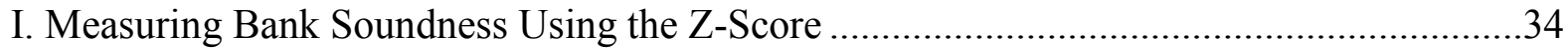

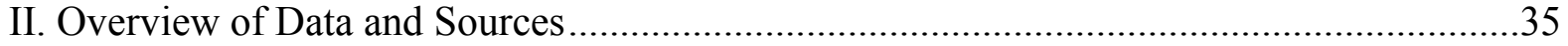

III. Turnovers in Small and Medium Sized U.S. Banks 1990-2007 ....................................36

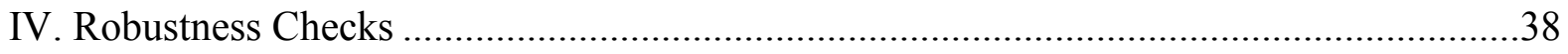


"John is a great banker, unfortunately he'd never been through the tough times of banking right now. ... He's not as seasoned as what we need in today's banking climate."

A Board member commenting on the departure of Riverside Bank CEO John Moran (June 10, 2008)

\section{INTRODUCTION}

Major losses incurred by a range of U.S. banks during the recent financial crisis have coincided with a number of forced departures of bank executives. In addition to some highly-publicized executive turnovers at widely-known institutions, such as Citigroup, Merrill Lynch, Wachovia, Washington Mutual, SunTrust Bank, and Bank One, there have also been numerous executive turnovers at smaller and perhaps less widely known banks, such as Douglass National Bank, Provident Bank of Maryland, Parkway Bank, Bank of Albuquerque, and Riverside Bank. ${ }^{2}$ To the extent that bank executives determine the funding and investment strategies of a bank, replacing an executive is a major event in the life of the bank.

In this paper, we use 18 years of data on small and medium-sized U.S. banks (average total assets USD 330 million) to test the extent to which a bank's perceived financial soundness and performance are significant contributors to the probability that an executive is forced to step down.

Our analysis has potentially important policy implications. The financial crisis has demonstrated substantial weaknesses in both supervisory monitoring and market discipline. ${ }^{3}$ To be able to address these weaknesses, it is important to understand how exactly the various channels of discipline have worked, or have failed to live up to their expectations.

Over the last decade, there has been a growing emphasis, both in the academic literature and in regulatory policy, towards strengthening market discipline. For instance, Calomiris (1999) and Evanoff and Wall $(2000,2001)$ propose adding a mandatory subordinated debt requirement to the risk-based capital regime. The potential for market discipline created by subordinated debt has also been considered extensively in a study by the Board of Governors of the Federal Reserve (1999). Similarly, changes in regulatory and legislative frameworks have placed increasing emphasis on the role of market discipline. In particular, one of the three pillars of the Basel II capital standard is the "market discipline pillar," reflecting the idea that if banks have to disclose more information, market participants will be able to harness this information to better

\footnotetext{
${ }^{2}$ Public attention to turnovers of bank executives is not constrained to the United States. Recent examples include IKB Bank, KfW Bank, and WestLB in Germany; UBS and Credit Suisse in Switzerland; Northern Rock, Abbey National, and HSBC in the UK; and Allied Irish Bank in Ireland, to mention just a few.

${ }^{3}$ Market discipline as used in this paper includes both the so-called internal market discipline (exerted by shareholders) and external market discipline (exerted by subordinated debtholders). See, for example, Boot and Schmeits (2000) for a further discussion of this terminology.
} 
assess banks' financial health, and trigger a change in behavior (Bliss; 2001; Basel Committee on Banking Supervision, 2004).

As a result, supervisory authorities have been conscious of the need to complement regulatory discipline with market discipline as a tool to limit the risk of costly bank failures (e.g., Park and Peristiani, 1998; Flannery, 1998; Berger, Davies, and Flannery, 2000; Shadow Financial Regulatory Committee, 2000; Bliss; 2001; Hancock and Kwast, 2001; Martinez Peria and Schmukler, 2001; Maechler and McDill, 2006; Ashcraft, 2008). Indeed, there is some evidence that the societal costs of bank supervision are lower if the responsibility of oversight is shared by supervisors and market participants (Martinez Peria and Schmukler, 2001). Thus, even today, as the financial crisis has led to major bank bailout packages around the world, there is recognition that changes to the current regulatory architecture will only be effective if market discipline can be credibly restored (Bernanke, 2009).

In the discussion of market discipline, it is important to differentiate between two dimensions: market participants' ability to monitor and evaluate a bank's condition, and their ability to influence a bank's actions (Bliss, 2001; Flannery, 2001, 2008). Most papers on market discipline only focus on the first dimension, and report evidence that risk-taking is associated with higher funding prices and/or fewer funding sources. In this context, market discipline is seen as a vehicle to reduce moral hazard created by implicit and explicit guarantees, such as deposit insurance schemes, and to improve bank efficiency by singling out underperforming banks. However, the recent wave of banking problems illustrates that monitoring mechanisms have either not materialized or have not been sufficient (Flannery, 2008).

We take a broader perspective addressing both dimensions of market discipline, and focus on stakeholders' (i.e., shareholders', debtholders', and supervisors') ability to discipline bank executives by forcing them to step down if their performance is no longer adequate. If this form of market discipline is effective, these stakeholders exert sufficient discipline on a bank's management to increase soundness well before the institution experiences serious distress. This hypothesis is consistent with the literature on corporate governance, which underscores the monitoring role of institutional shareholders (e.g., Kini, Kracaw, and Mian, 2004; Parrino, Sias, and Starks, 2003). Furthermore, focusing on discipline in the labor market for executives reflects that executives have an incentive to establish themselves as value-enhancing individuals that act in the interests of equity holders in the hope of more lucrative jobs in the future (Bliss, 2001). Cannella, Fraser, and Scott Lee (1995) show that labor markets can indeed differentiate between executives that are likely to be responsible for their banks failures and those who are not. Similarly, Farrell and Whidbee (2000) report that outside directors who were not aligned with CEOs ultimately fired have a lower probability of losing their directorships and are more likely to be appointed to additional directorships at other firms.

Our analysis contributes to the literature in several ways. First, we focus on a new 'face' of market discipline: the relation between forced executive turnovers, bank risk, and losses. Second, 
we identify several potential sources of market discipline, and examine how each of them influences the likelihood of firing a bank executive in response to risk-taking and losses. Third, we collect a unique dataset: while most studies focus on large and publicly listed banks (e.g., Flannery and Sorescu, 1996), we bring to bear a unique, hand-collected, dataset of executive turnovers observed in small and medium-sized banks in the United States between 1990 and 2007. The focus on small and medium-sized banks enables us to study the effect of discipline in a 'laboratory setting', in which weak banks have little or no expectation of being bailed out. ${ }^{4}$ As a result, the empirical regularities we observe are unlikely to be confounded by various forms of government guarantees. Fourth, we also offer a methodological innovation and introduce a conditional logit model into the banking literature. As detailed further below, this modeling technique is ideally suited for samples that consist of treatment and matched control groups.

We find that executives are more likely to be removed if their bank is financially weak (this effect is also observable for banks that rely on subordinated debt), reduces dividend payments, and has a high charter value. Moreover, we uncover a strong and persistent effect arising from losses, but we find no evidence that regulators discipline executives. We can also rule out that risk factors are associated with voluntary turnovers. Our results, which are robust to alternative definitions of bank executives, subsamples in which we remove failed and merged banks, and accounting for closely held share ownership, estimation methods, confirm our hypothesis that forced executive removals represent an important face of market discipline. Finally, an ex-post analysis of the performance and risk profile of turnover banks following firings provides only weak evidence for reductions in bank risk but suggests improvements in terms of performance. However, when we examine performance after forced turnovers relative to a control group of comparable institutions, we do not find that forced dismissals lead to lower bank risk. These results suggest that while bank executives are sensitive to the threat of a forced turnover, this threat may not be sufficient to curb risk-taking, perhaps because it occurs too late or because it takes a long time for a new manager to change a bank's strategy.

The structure of the paper is as follows. Section II develops our hypothesis, based on a brief synopsis of the related literature. Section III explains the methodology and dataset. Section IV reports on performance of banks prior to the forced turnovers, Section V presents the results from our multivariate analysis and from the examination of bank performance following turnovers. We offer concluding remarks in Section VI.

\footnotetext{
${ }^{4}$ Market discipline requires a high level of transparency and no support expectations (Nier and Baumann, 2006; Gropp, Vesala, and Vulpes, 2002; Covitz, Hancock, and Kwast, 2004; Stern and Feldman, 2004). In addition, our sampling horizon covers primarily the post FDICIA period, where scope for regulatory forbearance for nonsystemically important banks is curtailed by the mandatory actions prescribed by the prompt corrective action (PCA) framework.
} 


\section{RELATED LiterATURE AND HYPOTHESIS}

A large body of literature examines traditional faces of market discipline. Typically, holders of uninsured liabilities (such as subordinated debt, bonds, or uninsured jumbo CDs) are assumed to have monetary incentives to monitor banks' risk return trade-offs and will therefore punish risky banks by either withdrawing funding or demanding appropriate risk premiums (e.g., Maechler and McDill, 2006). While these forms of market discipline have received considerable attention in empirical work, ${ }^{5}$ we focus on a new face of market discipline: the threat of a bank executive being dismissed as a result of excessive risk-taking and incurring losses for the bank. The intuition is that a forced departure taints the reputation of an executive and truncates job prospects in the future (Cannella, Fraser, and Scott Lee, 1995).

So far, the relation between bank risk, losses, and executive turnover has received little attention in the literature. This is remarkable, given that the role of market discipline as a means to improve the safety and soundness of the banking system has gained prominence in the literature, and is increasingly seen as a complement to regulators' efforts to discipline banks (e.g., Flannery, 2001; Basel Committee on Banking Supervision, 2004). ${ }^{6}$

The nexus between executive turnover and firm performance more generally has been the subject of extensive research in the corporate finance literature. Influenced by the work of Shleifer and Vishny (1986) that suggests a critical role for large blockholders in monitoring firm performance, a vast body of literature has evolved on how effectively boards monitor executive behavior and how they hire and fire executives (for a review, see Huson, Malatesta, and Parrino, 2004). The consensus in this literature is that boards of directors can monitor firm performance and act to replace executives of poorly performing firms. Indeed, the threat of dismissal for poor performance seems to be an important motivation for executives to maximize shareholders' value (e.g., Coughlan and Schmidt, 1984; Warner, Watts, and Wruck, 1988; Hadlock and Lumer, 1997; Renneboog, 2000). According to these studies, the negative relation between return performance and CEO turnover is stronger for companies with outsider-dominated boards (Weisbach, 1988) and in high competition industries (De Fond and Park, 1999). Furthermore, Huson, Malatesta, and Parrino (2004) find that performance follows a v-shaped pattern,

\footnotetext{
${ }^{5}$ Several studies examine risk premiums in bond markets, in particular for subordinated debt, e.g., Flannery and Sorescu (1996), Covitz, Hancock, and Kwast (2004), Evanoff and Wall (2001), Morgan and Stiroh (2001), Hancock and Kwast (2001), and Sironi (2001). Focusing on the quantity effects of depositor discipline, Goldberg and Hudgins (2002) show that failing banks experience declines in uninsured deposits prior to failure, whereas Billet, Garfinkel, and O'Neal (1998) show that banks that received ratings downgrades substitute outflows of uninsured liabilities with insured deposits. Price and quantity effects of depositor discipline are the subject of work by Park and Peristiani (1998), and Maechler and McDill (2006). Schaeck (2008) takes a different approach in his examination of market discipline and provides evidence that banks that are relying excessively on uninsured liabilities tend to fail faster.

${ }^{6}$ Note that finance theory proposes that any firm's outside claimants influence managers and owners to act in their interests (Flannery, 2001). This influence is exerted via the elected board, shareholder activism, and, ultimately, corporate control (see Renneboog, 2000, for additional details).
} 
declining prior to a CEO turnover and improving afterwards. They also find that turnover announcements themselves can lead to stock price increases, a result that is in line with Clayton, Hartzell, and Rosenberg (2004), who report strong evidence for large and long-lived increases in stock price volatility after forced turnovers of CEOs.

The banking counterpart to this literature, which remains very narrow, finds similar results. Based on a sample of banks in the 1980s, Barro and Barro (1990) find that the probability of CEO departure depends on performance, as measured by peer-group stock returns. Houston and James (1995) also report an inverse relation between return performance and CEO turnover, whereas Hubbard and Palia (1995) show that executive turnover increases substantially after deregulation in the banking industry. More recently, Webb (2008) finds a strong positive relation between the intensity of supervisory monitoring and CEO turnovers in U.S. publicly-traded banks during the 1992-2004 period. However, none of these articles emphasizes the effects of bank risk and losses (the ex-post materialization of risk) on executive turnover.

We argue that the threat of a forced turnover is an important face of discipline, as it can capture a number of direct and indirect channels through which executives can be penalized. These channels, which may be complementary, aim at disciplining executives that take on excessive risk, or whose strategies give rise to bank losses.

- $\quad$ Shareholders. Shareholders, particularly large shareholders, have greater incentives to monitor managers than other stakeholders, because large shareholders receive benefits from their monitoring activities that exceed the costs incurred from monitoring (Grossman and Hart, 1980; Shleifer and Vishny, 1986). In addition, large shareholders, which may be represented on the board of directors, or bank holding companies, can exercise direct influence on corporate decisions, including the appointment and removal of executives. ${ }^{7}$

- Debtholders. While debtholders do not normally acquire direct control rights, they can indirectly influence executive behavior via two distinct avenues (Flannery, 2001): (i) owners and executives understand that risk-enhancing activities impact on the price and quantity of future debt funds (e.g., Morgan and Stiroh, 2001; Maechler and McDill, 2006); and (ii) bondholders can affect bank behavior through ex-ante covenants designed to constrain leverage, asset substitution possibilities, and ownership structure. Ultimately, such pressure exerted by debtholders can contribute to and facilitate the turnover of a bank executive.

- $\quad$ Supervisory agencies and regulators. Supervisory agencies and regulators can directly influence executive turnover. In particular, when a bank's capitalization falls below a predetermined threshold level, the Federal Deposit Insurance Corporation (FDIC) can

\footnotetext{
${ }^{7}$ Shareholders can also 'vote with their feet' (e.g., Parrino, Sias, and Starks, 2003) by disposing of their shareholdings rather than engaging directly into the corporate decision-making process.
} 
require the bank to conduct a new election of the board of directors, or force an executive turnover under the prompt corrective action framework.

These arguments suggest formulation of the following hypothesis.

Hypothesis: $\quad$ Rising bank risk and/or the materialization of large losses induce stakeholders (i.e., shareholders, debtholders, and/or supervisory agencies)

to discipline behavior of the bank executives by increasing the probability of forcing them to step down.

\section{Methodology And Data}

\section{A. Methodology}

In the presence of internal and external discipline, an executive should face a higher risk of being replaced when her bank has a higher risk profile and/or when losses are incurred. We therefore model executive turnover as a function of banks' risk profiles, losses, and a set of control variables. We also isolate the disciplining effects arising from different stakeholders and explore how each one of them individually exerts discipline. In particular, we model debtholder discipline (i.e., discipline exerted by holders of debt instruments), shareholder discipline (i.e., discipline exerted by shareholders), and supervisory discipline (i.e., discipline exerted by banks' supervisors). The explanatory variables are lagged by one period to avoid detecting contemporaneous correlations. ${ }^{8}$ Thus, forced turnovers are modeled as follows:

Turnover $=f($ discipline, risk, losses, bank characteristics).

We use a conditional logit regression technique that permits outcome probabilities to depend on choice-specific characteristics (Chen, 2004). ${ }^{9}$ This methodology is more appropriate than a standard logit model because of the nature of our sample, which is constructed using a matching method, as detailed in Section III.C. below. The difference to a standard logit model lies in the fact that the data are grouped, whereby a group consists of one bank with a forced turnover and a set of banks from a matched control group that did not experience any forced turnovers. In the conditional logit model, the likelihood for the forced turnovers is calculated relative to each group. ${ }^{10}$

\footnotetext{
${ }^{8}$ This lag is further reinforced by the fact that some information for the right hand side variables is only available with a time lag.

${ }^{9}$ Conditional logit models are widely used in biostatistics and epidemiology when experiments are conducted using matched case-control studies with 1: $k_{n}$ matching, where $k$ denotes the number of matches and $n$ is the total number of groups.

${ }^{10}$ In unreported regressions, we reestimate our models with a standard logit model and obtain similar results.
} 


\section{B. Variable Selection}

In this section, we discuss the variables we use in our analysis and provide details about the construction of the measures of turnover. The choice of variables is driven by theoretical considerations and data availability.

The dependent variable is a dummy variable Turnover that takes on the value of one if we observe a forced turnover or zero otherwise. Section III.C contains a detailed discussion of the definition of forced turnovers.

The explanatory variables capture the different sources of discipline, while controlling for other factors that have an influence on forced turnovers. Discipline can be exerted by the following parties: (i) debtholders, in particular depositors and holders of subordinated debt; (ii) providers of equity capital, i.e., shareholders; and (iii) regulators and supervisory agencies. To empirically isolate the different sources of discipline, we use a variety of explanatory variables. In addition, to capture the ex-ante build-up of risk and the ex-post materialization of risk (in terms of losses) on the decision of different stakeholders to dismiss executives, we also include a risk variable and losses in our regressions.

\section{Debtholder discipline}

First, we focus on the role of debtholders. Flannery and Sorescu (1996) have shown that holders of subordinated debt have the ability to differentiate between sound and risky banks. Whilst debtholders cannot directly force an executive turnover, their ability to seek compensation for higher bank risk via higher yields and the possibility to refuse the rolling over of debt can discipline a bank, and can ultimately fuel the turnover of an executive. As a result, to assess the role of debtholders we use the ratio of Subordinate debt to total assets to allow for the possibility that holders of uninsured subordinate debt exert discipline. Thus, a bank with a higher share of subordinated debt is expected to experience a higher turnover.

Next, we construct a variable Core deposits to total assets that covers all insured depositors (i.e., deposits smaller than 100,000 U.S. dollars). This variable plays a dual role. According to the traditional depositor discipline literature, it captures the role of insured depositors, which are usually assumed to have less strong incentives to monitor the risk profile of their banks (e.g., Goldberg and Hudgins, 2002). According to the charter value literature (Goyal, 2005), however, a high share of core deposits to total assets can help curb bank managers' risk taking and consequently decrease the likelihood of a forced turnover. The idea is that customer deposits represent a very stable and relatively cheap funding base, which greatly facilitates banks' operations. Thus, a large deposit base represents a high "charter value", in the sense that such a bank would have more to lose by engaging in excessive risk taking than other banks that rely on more expensive funding sources. Under this hypothesis, we expect a bank with a higher share of core deposits to experience higher turnover. 


\section{Shareholder discipline}

We examine several variables to capture how shareholders discipline bank managers. First, we introduce Relative profits, calculated as the difference between the ROE of the bank and the median ROE in the banking industry during that period. This variable is expected to show a negative sign, as shareholders are likely to be more satisfied with bank management (i.e., impose lower executive turnovers), when they earn a relatively higher level of dividends. This is consistent with the corporate finance literature, which suggests that profits are inversely related to executive turnovers (Hadlock and Lumer, 1997; De Fond and Park, 1999).

Second, we also construct a dummy variable, Bank Holding Company member (BHC member), that takes on the value one if the bank is a member of a bank holding company. This is to test the hypothesis that a bank that is part of a bank holding company may be subject to more complex risk management and stricter monitoring because BHCs boards have more committees and meet more frequently than other boards (Adams and Mehran, 2003). Research for other industries suggests that concentrated shareholding indeed improves monitoring (see Yafeh and Yosha (2003) for evidence from the Japanese chemical industry). Consequently, we anticipate a bank holding company to have a higher sensitivity to risk, so that the BHC dummy is likely to enter with a positive coefficient.

It is important to account for shareholders' desire to receive steady income from their shareholdings because regular increases in dividend payments tend to be common for U.S. banks (Bessler and Nohel, 1996). We therefore include Dividend volatility, measured by the standard deviation of dividend payments in USD over eight quarters prior to the executive's departure date, and a dummy variable Dividend cut, that takes on the value one if the dividend payment was reduced during the previous period. Dividend volatility aims to capture a medium term effect of dividend payments on turnovers whereas the dividend cut dummy captures an immediate effect on the dependent variable. The intuition is that changes in dividend payments convey private information to outsiders, e.g., about a bank's loan portfolio (Bessler and Nohel, 2000). Changes in dividend payments are therefore a credible way of reducing information asymmetries between banks and their shareholders. For instance, if dividend cuts signal severe problems in a bank, customers may discontinue lending relationships and depositors are likely to withdraw. In contrast, steady dividend payments strengthen confidence in the bank (Bessler and Nohel, 1996). Thus, shareholders are likely to consider dividend reductions and high volatility of dividend payments as strong signals about the viability of the bank. For both these variables we expect a positive sign in our regressions.

\section{Supervisory discipline}

To capture supervisory discipline, we use a Supervisory Intervention Dummy (SI Dummy). We construct the variable based on the prompt corrective action (PCA) framework applied by the U.S. supervisory authorities (see, e.g., Benston and Kaufman, 1994). According to the PCA framework, if a bank's Tier 1 capital breaches 3 percent of its average total assets, the FDIC can 
require the bank to hold a new election for the board of directors, or dismiss directors or senior executives and demand their replacement. In the absence of more detailed supervisory data, we construct a simple regulatory intervention dummy, which takes the value of one if the bank's total equity ratio falls below 6 percent and zero otherwise. ${ }^{11}$ This variable approximates if the turnover is due to regulatory pressure rather than discipline exerted by the market. A bank under supervisory scrutiny is expected to experience a higher executive turnover. ${ }^{12}$

\section{Losses}

We also construct a variable Losses (in logs) to capture losses explicitly. The loss variable is set to zero if the bank makes a profit or takes on the absolute value of negative net income +1 to avoid taking the log of zero. Our intuition is that it may be that stakeholders are tolerant towards high levels of risk as long as the bank remains profitable. As a result, it may be that losses ultimately trigger the forced departure of executives. The loss variable is expected to enter the regression equations with a positive sign. ${ }^{13}$

\section{Bank soundness measure}

We use Z-Scores to measure bank risk. The Z-Score is a popular measure of soundness because it combines banks' buffers (capital and profits) with the risks they face (measured by the standard deviation of returns) in a way that is grounded in theory. Put simply, it measures how many standard deviations a bank is away from exhausting its capital base (see Appendix I for details). A higher Z-Score implies a lower probability of insolvency, providing a more direct measure of soundness than, for example, simple leverage measures. We calculate the Z-Score as

$$
Z=\frac{(R O A+E / A)}{\sigma R O A}
$$

\footnotetext{
${ }^{11}$ A bank is classified as significantly undercapitalized when the Total risk-based capital is below 6 percent, Tier 1 risk-based ratio falls below 4 percent, and Tier 1 leverage-ratio is below 4 percent. However, since the Call Report data do not contain information about Total risk-based capital, Tier 1 risk-based capital, and Tier 1 leverage ratio prior to 2001, we approximate the threshold level by constructing a dummy variable that takes on the value 1 if the bank's total capital ratio falls below 6 percent. The correlation between the total capital ratio and total risk-based capital is 0.91; the correlation between the Tier 1 risk-based ratio and the Tier 1 leverage-ratio is 0.78 .

${ }^{12}$ In untabulated tests, we use information about formal enforcement decisions (e.g., cease and desist orders, and removal/prohibition orders) that we collect manually from the FDIC's website

(http://www.fdic.gov/bank/individual/enforcement/begsrch.html) as an alternative to the supervisory intervention dummy based on capitalization. Using this alternative measure of supervisory intervention has no effect on our results and we therefore do not report them (available upon request).

${ }^{13}$ We have also examined whether scaling losses by total assets changes our results. The results remain virtually unchanged and can be obtained from the authors upon request.
} 
where ROA is the bank's return on assets, E/A denotes its equity to asset ratio and $\sigma R O A$ is the standard deviation of return on assets computed for a three-year rolling time window. We use a three-year rolling time window for the $\sigma R O A$ to allow for sufficient variation in the denominator of the Z-Score. This approach avoids that Z-Scores are exclusively driven by variation in the levels of capital and profitability.

\section{Control variable}

The corporate finance literature suggests that larger firms experience higher turnover rates, reflecting promotion and retirement policies that reduce tenures in executive positions (Warner, Watts, and Wruck, 1988). To take this argument into account, we control for Size, measured by total assets $(\log )$.

\section{Interaction terms}

We also introduce a number of interaction variables to capture some of the non-linearities between our risk measure and key variables. For example, the interaction between the Z-Score and asset size tells us whether a bank executive faces a higher probability of being fired as risk rises if the bank is large. Similar interaction variables are created for subordinated debt (to capture whether the presence of subordinated debt raises the likelihood of an executive being fired in response to higher risk-taking), for core deposits (to capture whether banks with a higher charter value are more likely to fire their executives when bank soundness deteriorates), and relative profits (to explore how relative profits affect the risk-sensitivity of a forced turnover). Since risk-management procedures in banks that are part of a holding company may be more sophisticated than in stand-alone banks, we also interact the Z-Score with the BHC membership dummy. Finally, we explore how a supervisory intervention influences the likelihood of firing an executive for a given level of risk.

\section{Dataset}

\section{Bank data and sample coverage}

We obtain bank data from the Quarterly Report of Condition and Income (Call Report). Given that we aim to investigate the nexus between bank soundness and executive turnover, our focus is on commercial banks, and we do not examine bank holding companies (BHCs), because we want to avoid possible contagion of the results due to non-bank activities in BHCs. The banks in our sample can be classified as small and medium-sized institutions; none of them is listed on a stock exchange. The mean balance sheet size of the banks in our sample is USD 330 million. Figure 1 illustrates that the subsamples of turnover and control banks exhibit broadly similar distributions. Exploiting this dataset helps shed additional light on the question of whether market discipline can effectively limit the risk taking behavior of those types of institutions. An 
important added benefit of excluding BHCs is that the tests are performed on a more homogeneous dataset.

Figure 1. Histogram of Total Assets

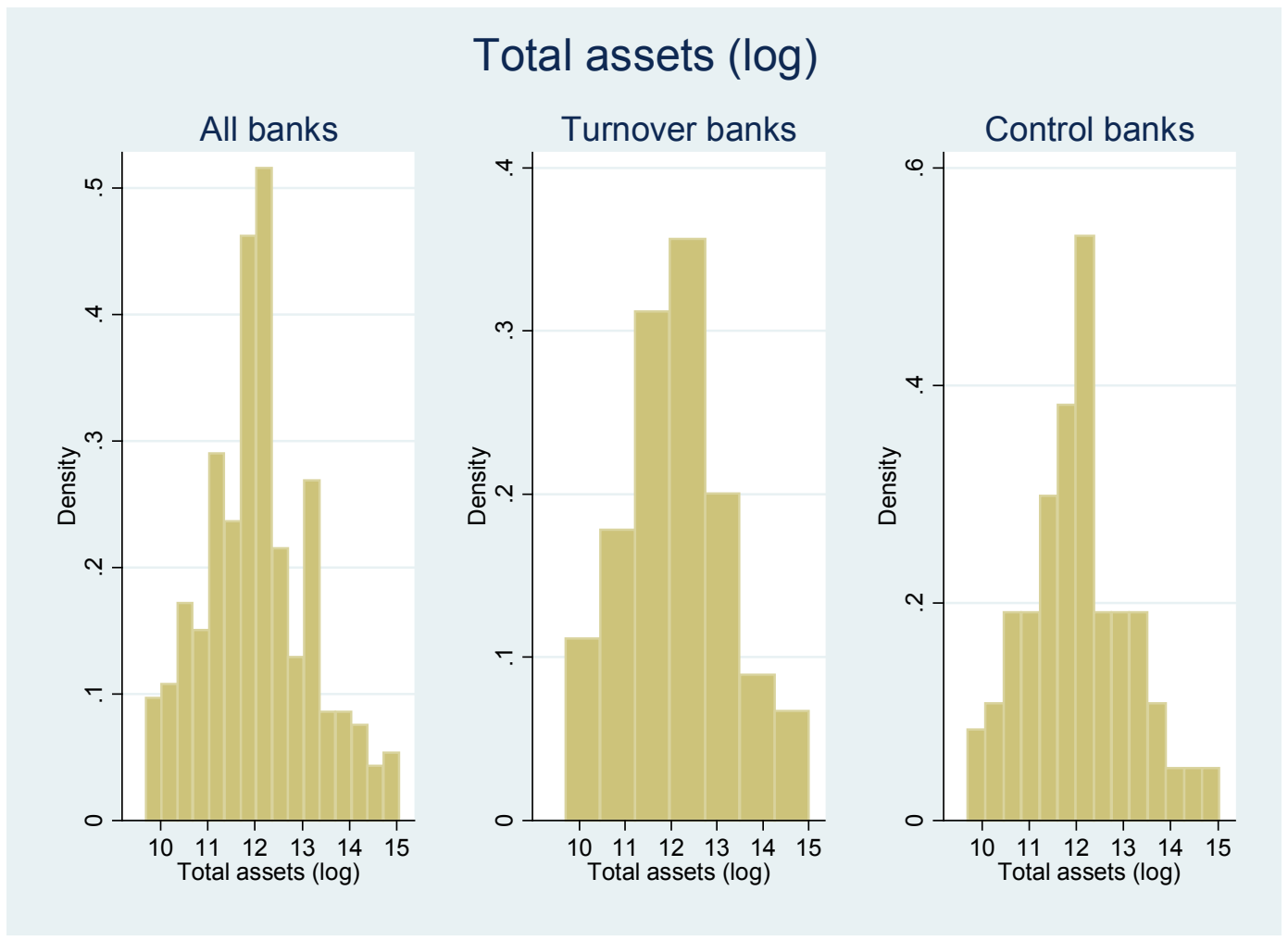

\section{Executive turnover data}

We use the LEXIS/NEXIS database, and employ a variety of key-word searches to differentiate between forced and voluntary executive turnovers in U.S. banks from 1990-2007. ${ }^{14}$ The year 1990 marks a good starting point, because the early 1990s were a period of major strengthening of regulatory powers for dealing with ailing banks (brought about by, e.g., the Federal Deposit Insurance Corporation Improvement Act, 1991).

Our initial search yields 661 articles from different sources, including well known international newspapers such as the Wall Street Journal, as well as regional U.S. newspapers and business journals. ${ }^{15}$ To identify whether the bank is a subsidiary, we access the official website of the

\footnotetext{
${ }^{14}$ We use the following keywords: management change, forced resignation, turnover, separation, ousted, early retirement, step down, mandatory/voluntary separation, fired, made redundant, departure, management succession, executive change and tenure. To assess the sensitivity of our keyword search, we also replicate the search using the NewsPlus/Factiva database, which yields very similar results (not reported).

${ }^{15}$ A list of all newspapers and trade and business journals we use for the analysis is available in Appendix II.
} 
bank and obtain company profiles from Reuters, Business Journal, Manta, and Goliath. We ascertain the executive's departure date and take the exact date of the turnover when it is reported. In case the departure date is not reported in the media, we take the date of the newspaper as departure date.

We adopt a broad definition of the term bank "executive," and define any individual that holds the position of president, chairperson, chief executive officer (CEO), chief financial officer (CFO), or chief operating officer ( $\mathrm{COO}$ ) as executive. Given that the main objective in our study is to analyze the relation between the channels of discipline and risk of the bank, we exclude all turnovers that occur in banking arms and divisions of the bank. We also do not differentiate between different types of turnover (e.g., a CEO versus a $\mathrm{COO}$ turnover). To identify our sample of executive turnovers, we follow the corporate finance literature (e.g., Parrino, Sias, and Starks, 2003), and establish a set of criteria that needs to be met for an executive turnover to be classified as forced.

We classify a turnover as "forced" if the executive is reported to have been fired, forced to step down or to have departed due to undisclosed policy differences. All remaining executive turnovers are classified as voluntary, unless they meet at least one of the following criteria:

- the departure is announced with the reason not being death, poor health, or acceptance of a position either elsewhere or within the bank,

- the executive is reported to retire but does not announce the retirement at least six months prior to succession,

- in case of non-informative reasons, forced turnover due to disciplining actions or due to company policy disputes is assumed.

Imposing these criteria, dropping multiple reports about the same institution, and dropping bank holding companies yields in total 90 forced turnovers. In Appendix III, Panel A, we present the list of banks that experience executive turnovers and the types of turnovers in the sample. The number of presidential turnovers dominates the sample with 48 turnovers, followed by CEO turnovers (27), and chairpersons (8). Newspapers devote less attention to turnovers of CFOs (2) and COOs (5) ${ }^{16}$ Panel B illustrates a bimodal distribution of our turnover data. For the period 1990-1998 we observe 48 executive turnovers, with a peak in 1994, and another peak in 2005. Between 1990 and 2007, we observe another 42 turnovers in total. Moreover, the data also indicate a slightly higher number of turnovers during the early years of the sampling period. This is likely to be influenced by the banking turmoil in the late 1980s and early 1990s. In recent

\footnotetext{
${ }^{16}$ As a consequence, we perform one robustness test and remove those turnovers where the turnover is observed exclusively for top executives, defined as either president, chairperson, or CEO.
} 
years, we observe another increase in the number of forced turnovers, reflecting on the sub-prime crisis starting in 2007.

In instances where an individual holds more than one role, e.g., CEO and chairman (also referred to as 'duality') and if we observe a departure, we count this as one turnover in our sample. This procedure reduces our initial set of 90 turnovers to 65 forced turnovers.

We note that the number of turnovers, 65, may appear low, given that there are thousands of banks in the U.S., and given that the sample covers 18 years of data. This is because the analysis focuses on forced turnovers only. If one included all turnovers (i.e., all situations when there is a change in the name of an executive), the number of turnovers in our sample would be at least 10 times higher. This is consistent with previous studies of turnover frequency in firms (bank and non-bank), according to which forced turnovers account for 10-20 percent of all turnovers (see Clayton, Hartzell, and Rosenberg, 2005). ${ }^{17}$

\section{Matching procedure}

The small sample of turnover banks raises an interesting question about what group of banks it should be compared to. For example, there are good reasons to believe that firm size and heterogeneity affect both managerial incentives and performance (e.g., Hubbard and Palia, 1995). To mitigate such selection bias issues, we follow a two-step approach and match our turnover banks with banks of similar characteristics.

In a first step, we access the National Information Center website, ${ }^{18}$ to match the banks for which we observe executive turnover with Call Report data, using location and name checks to facilitate our matching procedure. This procedure allows us to match the 65 executive turnovers with balance sheet and income statement data for the banks during the period 1990-2007.

In a second step, we construct our estimation sample to find similar banks in which no turnover is observed. To this end, we use a matching method based on bank size, location, and time period. The size criterion ensures that we compare banks with similar operations in terms of scale, business model, and macroeconomic conditions. Location and time period are used as additional matching criteria because the banks are primarily small and medium-sized institutions that are likely to be affected by local macroeconomic conditions in a similar manner.

\footnotetext{
${ }^{17}$ Studies of forced executive turnovers tend to operate with small sample sizes. For instance, Farrell and Whidbee (2000) perform their analysis of the consequences of forced CEO turnovers with a sample of 66 forced turnovers for the period 1981 to 1992.

${ }^{18} \mathrm{http}$ ://www.ffiec.gov/nicpubweb/nicweb/SearchForm.aspx.
} 
For each bank for which we observe a turnover, we identify at least one matched bank at the same point in time that is located in the same state and is of similar size. We measure size by total assets, and consider a bank to be a good match if its total assets are between 80 and 120 percent of the bank for which we observe a turnover. If several banks qualify as matches, we restrict the number of matches to the four banks that are closest in terms of their asset size. ${ }^{19}$

For six banks from our original turnover sample we cannot find a matching bank. Thus, our final sample consists of 59 banks with turnovers (henceforth referred to as the "treatment" group) and a group of 219 matched banks (henceforth referred to as the "matched" group) that is available for our most parsimonious regression specification.

Since we are cautious to undersample closely held opaque banks that may not report executive turnovers, we examine the proportion of S-Corporations in our sample relative to the proportion in the population of banks in the Call Reports. ${ }^{20}$ The structure of our sample mimics in that sense rather well the structure of the entire population of small and medium-size banks. The proportion of S-Corporations in the sample is nearly identical to the proportion of S-Corporations in the population (12.7 percent vs. 12.4 percent, respectively).

We also examine whether our newspaper sources are clustered in certain regions in the U.S, which could lead to the oversampling of banks located in these areas. While many of the newspapers are indeed headquartered in large metropolitan areas (e.g., New York, Chicago, Los Angeles), we also include numerous news sources from more rural regions, such as Alabama, Kentucky, Nebraska, and Vermont (Appendix II). This approach reduces the risk of oversampling areas with higher levels of media concentration. ${ }^{21}$

Summary statistics for the banks in the turnover and matched groups are presented in Table 1. The last two columns of Panel A in Table 1 present t-tests to show whether the means and medians of key variables differ across the two samples at conventional levels of significance. The tests confirm that banks across the two samples do not differ in terms of asset size but exhibit considerable differences in their risk profiles and losses. We show correlations for the variables we use in the empirical tests in Panel B.

\footnotetext{
${ }^{19}$ Using the LEXIS/NEXIS database, we verify that no executive turnover is reported for the banks in the matched group.

${ }^{20}$ An S-Corporation is a form of corporate organization available to firms with small numbers of shareholders. SCorporations are entities that must not have more than 100 shareholders, and have only one class of stock. SCorporations do not pay corporate income taxes. Instead, the profits are reported on the owners' tax forms, and hence are taxed at the personal tax rate.

${ }^{21}$ We have no newspaper sources from the following states: Arizona, Delaware, Idaho, Mississippi, Montana, New Mexico, North Dakota, South Dakota, Oklahoma, Oregon, Utah, and Wyoming.
} 
In particular, our two measures of bank risk, the Z-Score (as the build-up of risk) and the loss variable (as the ex-post materialization of this risk), indicate that banks that have their executives replaced are riskier than the institutions in the control group. For instance, banks that have their executives forcefully removed are on average less than 40 standard deviations away from exhausting their capital, in contrast to banks in the control group which are more than 80 standard deviations away from depleting their capital. Similarly, the losses recorded in turnover banks are on average more than eight times larger than in banks in the control group. These differences are significant at the one percent level. We find that banks with forced turnovers exhibit greater dependence on subordinated debt, and experience more frequent interventions by the supervisor. The data also indicate differences in the number of dividend cuts.

Our data also allows us to shed some light on the relations between forced turnovers and changes in banks' corporate structure. The results are presented in Panel C of Table 1. Only nine of the banks in which we observe forced turnovers were involved in merger activities (four acquired another institution and five were taken over), whereas 18 of the banks in the control group were involved in M\&A activities. Panel $\mathrm{C}$ also shows that seven of the banks in which executive turnovers took place failed ultimately. However, the failures took place at least two years after the turnover and in many instances more than five years after the forced departure. ${ }^{22}$

\section{Bank Performance Prior to Executive Turnover}

We conjecture that executive turnovers are preceded by deterioration in performance. Clearly, if a bank is headed for trouble that eventually triggers a forced turnover, we may be able to observe a decline in performance well ahead of the departure of the executive. This is shown in Table 2, which illustrates the percentage changes in Z-Scores, ROE, relative profits, and losses in a period of three years prior to the executive's departure.

Our results confirm that Z-Scores decline, although not monotonically, in banks that experience forced executive dismissals over the three years prior to departure. For instance, in the year before the executive gets fired, Z-Scores decrease on average by more than 7 percent and the median ROEs decline on average by 62 percent. The deterioration of profits is particularly significant with a decline of 27 percent over the three years prior to a forced turnover. Likewise, the decline in relative profits (measured by relative ROE) exhibits a similar pattern, with the strongest decline in the year preceding the turnover, and further decreases, although less substantial, two and three years prior to the turnover. In contrast, losses only skyrocket in the year prior to the turnover, increasing by about 118 percent.

\footnotetext{
${ }^{22}$ Additional details are available upon request.
} 


\section{Multivariate Analysis}

To capture the relations between bank risk, losses, the different sources of discipline, and forced executive turnovers, we use a conditional logit model specification. In this set-up, the dependent variable takes on unity for banks in which we observe a forced turnover or zero otherwise. We present results in Table 3.

\section{Different sources of discipline and executive turnover}

Column 1 shows that firings are more likely to be observed in banks that are financially weak. This is captured by the coefficient of the Z-Score, which is negative and significant at the one percent level. The point estimate for the loss variable enters positively at the five percent significance level, underpinning our hypothesis that losses in the period preceding the turnover are associated with forced turnovers. Increased reliance on subordinated debt funds is also correlated with the risk of turnover at the five percent significance level, confirming the disciplinary role of subordinated debtholders. ${ }^{23}$

We interpret these results as constituting novel evidence for a thus far unnoticed face of market discipline - the executive's exposure to the risk of being forced out of her job. Moreover, our findings lend some support to the idea that market discipline is present in small and mediumsized banks that tend to be less subject to public scrutiny than their large and listed counterparts. We note, however, that this result is obtained in a narrowly defined sample of banks that are unlikely to be subject to regulatory forbearance or implicit support guarantees. In that sense, the risk of moral hazard arising from an expected governmental support appears very limited even if banks are less subject to public scrutiny.

None of the other variables assume significance at conventional levels in Column 1 . The two measures for shareholder discipline, the BHC membership dummy and relative profits, have no significant ramifications for executive turnovers. A number of reasons may explain this finding. One possible explanation is that governance arrangements (e.g., through the BHC group structure) are not sufficiently binding in small BHCs to discipline executives. It may be that boards of banks that are BHC members are larger and are less effective monitors due to greater communication problems. Alternatively, board members could be represented on multiple bank boards and may be concerned about losses in reputation if they dismiss poorly performing executives, or, finally, BHCs may free-ride on bank supervisors with respect to their monitoring duties.

To adjust the regressions for shareholders' desire to receive steady cash flows from their dividends, we include dividend volatility and a dummy variable for reductions in dividend

\footnotetext{
${ }^{23}$ This result in consistent with the literature on subordinated debt (Flannery and Sorescu, 1996; Covitz, Hancock, and Kwast, 2004; Evanoff and Wall, 2001; Morgan and Stiroh, 2001; Hancock and Kwast, 2001; Sironi, 2001).
} 
payments in Column 2. While the volatility of dividend payments in the eight quarters prior to turnovers remains insignificant, the dividend cut variable indicates a significantly positive association with turnovers. Reducing dividend payments increases an executive's probability of losing her job as shareholders may be concerned about the viability and future prospects of the institution.

The positive and significant effect arising from core deposits in Column 2 further suggests that depositors are able to exert discipline on executives. This result supports the idea that executives in banks with a high charter value have an incentive to act more prudently.

In Column 3, we include a number of interaction terms to examine how different bank characteristics influence the elasticity of forced turnover with respect to bank soundness. We find that larger banks are less willing to fire their executives for a given increase in risk. We believe that this result is largely driven by the low likelihood of government support in small banks, further reinforcing investors' incentives to monitor and limit risk-taking in these banks. None of the other interaction variables are statistically significant.

In Column 4, we augment our specification with a supervisory intervention dummy to account for regulatory discipline. The estimated coefficient for this variable remains insignificant. This result could reflect, in part, the narrow definition of our supervisory intervention, which does not capture the full range of actions available to supervisors to address deteriorating bank risk (i.e., supervisory intervention is likely to occur well before a bank's capital hits the specific trigger point implied by our regulatory dummy). Since data on supervisory visits in small banks are not readily available, we cannot evaluate this mechanism in greater detail. The coefficients for the other key variables (i.e., Z-Score, losses, subordinated debt, dividend cuts, and core deposits) remain in line with those of our baseline specification.

We include another interaction term between bank risk and the supervisory intervention dummy in Column 5. The supervisory dummy and its respective interaction term remain insignificant while our previous findings remain largely unaffected.

To interpret the economic significance of our results, we report in Column 6 the change in the odds ratios for a one standard deviation increase in the significant variables from Column 5 (we use a unit increase in the case of the dividend cut dummy variable). Our calculations indicate that a one standard deviation increase in the Z-Score is associated with a reduction in the odds of an executive to be forcefully removed by a factor of 0.19 . In contrast, increasing losses or core deposits by one standard deviation is correlated with increases in the odds of observing a turnover by factors of 2.42 and 1.72 respectively. Dividend cuts are associated with an increase in the odds of being fired by a factor of 12.29 . 


\section{Ruling out the effect of risk and losses on voluntary turnovers}

In Column 7 of Table 3, we rule out that our regressions pick up spurious associations between forced turnovers and key variables. To this end, we verify that our statistically significant variables are not associated with voluntary turnovers so that a disciplining effect only arises from risk and losses for forced turnovers.

First, we use the information on voluntary turnovers for CEOs, presidents, chairpersons, CFOs, and COOs from our initial data collection procedure, and match banks in which we observe voluntary turnovers with a set of banks in which no turnovers are observed using the same matching procedure as described in Section III.C. Applying these criteria yields a dataset consisting of 137 banks of which 32 recorded voluntary turnovers. ${ }^{24}$ Second, we re-run the specification of Column 5 on our voluntary turnover dummy variable. We find no significant associations between our key variables of interest and voluntary turnovers. Based on this test, we can rule out that our disciplining effects arising from risk and losses for forced turnovers are spurious in nature. Also, these findings indicate that forced and voluntary turnovers are fundamentally different from each other. In our regression, only the interaction between size and the Z-score shows a significantly negative coefficient. This suggests that there is a higher probability for an executive to leave voluntarily as bank financials deteriorate if the bank is large.

\section{Goodness of fit}

To evaluate the goodness of fit, we compute predicted probabilities of observing a turnover (conditional on a positive outcome within each group) and assume the predicted outcome to be unity if the probability calculated from the conditional logit model exceeds 0.5 . In addition, we also report Type I and Type II errors.

In Table 3, column 5 predicts 73 percent of the turnovers correctly (31 of 42). On average, our models classify 61 percent of the forced turnovers correctly. The diagnostics for Type I and Type II errors suggest that we overpredict forced turnovers on average in 25 percent of our tests, whereas only 12 percent of the actual turnovers are misclassified on average.

To further examine the goodness of fit, we investigate the distribution of key variables across the percentile distribution of Z-Scores (Table 4). The mean Z-Scores range from 2.29 for the weakest banks to 231.21 for the soundest institutions. While the most unsound banks have the highest losses, no losses are recorded for the banks located at the upper tail of the distribution of the Z-Score. The mean ROE is improving and turning positive, although not monotonically, as

\footnotetext{
${ }^{24}$ The initial sample of voluntary turnovers is larger and consists of 45 voluntary turnovers during the sampling period for which public information is available. However, for many of those banks no matching bank can be found which explains the smaller sample size for the voluntary turnovers. Additional details are available from the authors upon request.
} 
we move up the distribution of the Z-Score. Finally, the last two columns depict the breakdown of the predicted and actual number of turnovers. To test how closely the predicted turnovers track the actual ones, we perform a Spearman rank correlation test and find that the rank order correlation between the predicted probabilities and the actual number of turnovers is 0.9329 . This correlation coefficient is significant at the one percent level, providing supportive evidence about the goodness of fit of our models.

We conduct a wide range of robustness checks, based on alternative definitions of bank executives, estimation methods, subsamples and matched sample sizes in Appendix IV. These tests leave our key findings virtually unchanged.

\section{Bank performance following executive turnovers}

Thus far, we investigated the nexus between risk and the probability of turnovers, and found some evidence for the presence of the first dimension of discipline in that sense that proxies for monitoring by shareholders and debtholders are significantly associated with turnovers.

In this section, we go one step further and use three alternative ways to investigate if the second dimension of market discipline whether the decision to remove a poorly performing executive influences risk-taking behavior. To do this, we examine whether a bank's performance improves after a forced turnover. If the new face of discipline is effective, we expect that performance improves following forced departures. ${ }^{25}$ In a first step, we focus on descriptive statistics in the periods following forced turnovers in the banks that had executives removed. In a second step, we compare descriptive statistics between the banks from the turnover and control groups, and, in a third step, we use a matching procedure based on propensity scores (Dehejia and Wahba, 2002) to address sample selection problems.

Under the first approach, we examine the extent to which the means and medians of the key variables (Z-Scores, ROE, relative profits, and losses) differ between the period of the forced turnover and one, two and three years afterwards in Table 5. This analysis indicates that significant improvements in terms of average Z-Scores can only be observed in the third year following a turnover, whereas no significant changes can be observed in terms of absolute ROE. The relative ROE improves significantly during the three years following turnovers, and we also find that the turnover banks significantly reduce losses following forced turnovers. Thus, there is some evidence that performance, but not risk, improves in banks that had their executive fired. These results are consistent with previous studies that report that executive turnovers affect firm operations (Clayton, Hartzell, and Rosenberg, 2005).

\footnotetext{
${ }^{25}$ Clearly, the underlying assumption is that executives matter for performance in the first place. Recent work by Bennedsen, Perez-Gonzales, and Wolfenzon (2006) shows that this is the case indeed. They provide strong evidence that deaths of CEOs and their family members give rise to economically and statistically significant declines in firm performance.
} 
In the second approach, we investigate differences between the banks with turnovers and the control group. The results (Table 6) confirm our earlier findings. Relative to the control group, we find that forced turnovers do not reduce risk profiles, at least not within three years following the forced turnover. The Z-Scores of the banks with a turnover remain significantly lower than those of the banks in the control group, even three years after the forced departure. The institutions in the control group operate at Z-Scores almost twice as high as the turnover banks' Z-Scores. In contrast, a forced executive turnover puts an end to the significantly higher losses experienced by the banks with turnovers, removing the statistical difference between the two groups. Return on equity and relative profits also do not differ significantly across the two groups.

Our results are confirmed when we use the propensity score matching estimator, suggesting that they are not tainted by a potential selection bias. ${ }^{26}$ In Table 7 , we match each bank with a turnover to a group of four banks that have the same probability of experiencing a turnover but have not experienced such a turnover. Any difference in Z-Scores, ROE, relative ROE, and losses can then be attributed to the forced removal of an executive. In other words, by estimating the average impact of turnover, we can draw inferences to what could have happened to, say, the Z-Score or the losses of a bank without a turnover, had this bank dismissed its executive.

The propensity score can be defined as the probability of firing an executive, conditional on a set of pre-turnover characteristics. ${ }^{27}$ As the propensity score is based on pre-turnover characteristics that should not be affected by the turnover itself, it is possible to calculate the propensity of observing a forced turnover based on a modified version of the model in Column 2 in Table 3, where turnover is modeled as a function of bank size, BHC membership, subordinated debt to total assets, core deposits to total assets, relative profits, dividend volatility, and dividend cuts.

The results in Table 7 support our earlier evidence that banks that fire their executive continue to experience significantly lower Z-Scores, even three years after the forced departure. This difference is consistently significant at the one percent level. We also find that banks with a turnover incur higher losses in the year following the turnover, but this difference remains

\footnotetext{
${ }^{26}$ The propensity score was first presented in Rosenbaum and Rubin (1983). More recent applications in the corporate finance include Bottazzi, Da Rin, and Hellmann (2008), and Bottazzi and Da Rin (2002).

${ }^{27}$ The propensity score estimator works as follows. Since we only observe forced turnovers for the treatment group, we are faced with a problem of missing data. To overcome this difficulty, we estimate the unobserved potential outcome for each bank with matching methods. The intuition is to estimate the untreated outcome for bank $i$ with a set of covariates $X_{i}$, which received treatment. Assuming that observing a forced turnover is random for banks that have very similar characteristics prior to the treatment, we calculate the average outcome of a set of similar banks that did not experience turnovers to estimate the untreated outcome. In other words, for each bank $i$, the matching estimator imputes the missing outcome by finding four banks with similar pre-treatment characteristics that did not receive treatment. Specifically, for every bank that has received treatment, the nearest-neighbor matching technique chooses a group of four untreated banks with propensity scores closest to the treatment bank propensity score. Our estimator then calculates an arithmetic average of the performance measure of these untreated banks.
} 
insignificant. The differences of ROE and relative ROE between treatment and control group also remain insignificant. Our results remain robust when expanding the number of matched banks from four to eight (not shown).

The findings in Tables 5, 6, and 7 indicate that turnovers have negative ramifications for risk. While Z-Scores increase in the three years following a forced turnover, these increases remain insignificant in the first and second year following a turnover. In fact, a more detailed analysis suggests that banks remain very risky in the periods following a potential turnover relative to the control group, and it takes three years before a significant improvement can be observed. The likely explanation is that dismissing bank executives is a very painful and problematic process. A new executive may need to restructure unsound bank activities and remove bad assets, which tends to further depress earnings. Moreover, the risk profile may also reflect the seriousness of the situation and overall uncertainty about the outlook for the bank. Forced turnovers may only occur in extreme cases, where other monitoring and soft disciplining devices no longer suffice. Depending on the underlying weaknesses, it may take time for a new strategy to translate into enhanced bank performance and for stakeholders to update their prior beliefs about the successor's ability to address the situation (Clayton, Hartzell, and Rosenberg, 2000). This uncertainty may be amplified in instances when an outsider is appointed as a successor because organizational changes are even greater following outside appointments (Farrell and Whidbee, 2000; Borokhovich, Parrino, and Trapani, 1996). Our evidence parallels findings in the corporate finance literature. ${ }^{28}$

In sum, while we only find weak evidence that bank risk is reduced following forced executive turnovers, our analysis provides some indication that firing executives is associated with reductions in losses and increases in relative ROE. However, relative to a group of comparable banks, there is no evidence that a disciplining effect translates into improved bank soundness, at least not in the short run. This does not necessarily mean that different sources of discipline do not have a beneficial impact on soundness. In fact, the threat of removing an executive may have a preventive impact, which is difficult to capture empirically. What we do find is that dismissing an executive does not help reduce dramatically a bank's risk exposure. This finding for small and medium-sized banks is not only plausible, but also consistent with evidence from large banks. For instance, Charles Prince resigned as CEO of Citigroup before large write-downs were taken and the bank received large government bailout assistance. Similarly, Stanley O'Neal resigned as chairman and CEO of Merrill Lynch, before the FDIC facilitated a merger with Bank of America.

\footnotetext{
${ }^{28}$ Huson, Malatesta, and Parrino (2004) show that executive turnovers are frequently followed by firm restructurings, and Weisbach (1988) highlights that new executives may even reverse the investment decisions of their predecessors.
} 


\section{Conclusions}

In this paper, we explore a face of market discipline that has not yet been adequately addressed in the literature. Specifically, we investigate the relations between a bank's risk profile and forced executive turnovers, while isolating different channels through which discipline can be exercised. Using a novel dataset of executive turnovers that sheds light on the efficacy of internal and external discipline for small and medium-sized banks in the United States between 1990 and 2007, we analyze the role of debtholders, shareholders, and regulators in bringing about executive turnovers.

We offer new insights into the micro-mechanism of internal and external discipline in a 'laboratory setting' by focusing on banks that are unlikely to be subject to regulatory forbearance or implicit support guarantees. Moreover, the dataset offers the additional benefit that it allows us to take a closer look at the efficacy of market discipline for banks that are not publicly listed. To examine the different channels of discipline, we combine our hand-collected dataset for executive turnovers with bank-specific data from Call Reports and use a matching procedure based on bank size, location, and time period to home in only on those banks that exhibit similar characteristics in terms of business model and macroeconomic environment.

Using conditional logit regression models, we obtain results that constitute novel evidence that forced bank executives turnovers are consistently associated with deteriorating bank soundness and losses. Higher levels of subordinate debt are also significantly correlated with turnovers, but the evidence is less robust. We also show that reductions in dividend payments and high levels of core deposits are consistently correlated with executive dismissals whereas no such associations exist in banks with voluntary turnovers of executives. In that respect, our findings support the idea that shareholders and depositors can be effective sources of discipline. These results are robust to alternative definitions of executives, alternative samples, and alternative estimation methods. The findings also remain qualitatively unchanged after adjusting our regressions for corporate control activity.

However, we find no evidence that being part of a bank holding company enhances discipline. The absence of a disciplining effect raises the question as to the efficacy (or willingness) of BHCs to monitor bank affiliates and, by extension, their corporate governance arrangements. Likewise, the lack of a significant impact of regulatory discipline indicates that supervisory interventions may not be sufficient to penalize poorly performing executives.

In a further analysis, we examine risk and performance following executive turnovers. We show that turnover banks remain risky in the years after an executive was fired, whereas losses are significantly reduced and returns remain significantly more risky, suggesting that the disciplining effect of forced turnover returns improve. However, in comparison to a group of comparable banks, turnover bankers remains limited. 
The recent financial crisis suggests that market, as well as regulatory, discipline has left much to be desired. Nevertheless, our analysis provides evidence that excessive risk-taking by bank executives did trigger disciplining behavior by stakeholders in small and medium-sized banks. Our analysis also sheds some light on which channels may be most effective as a means for strengthening discipline. In particular, we find that shareholders and small depositors can play an important role for disciplining bank executives and that exposure to subordinated debt can provide a form of market discipline in small and medium-sized banks. This finding offers some indication that, if complemented by a sound regulatory framework, debtholder discipline can play a helpful role. 
Table 1. Descriptive Statistics, Differences of Means and Medians, and Correlations

\begin{tabular}{|c|c|c|c|c|c|c|c|c|c|c|c|c|c|c|}
\hline \multirow{2}{*}{$\begin{array}{l}\text { Panel A } \\
\text { Variable } \\
\end{array}$} & \multicolumn{5}{|c|}{$\begin{array}{l}\text { Matching group: Banks w/o turnovers } \\
\text { (TURN }=0 \text { ) }\end{array}$} & \multicolumn{5}{|c|}{$\begin{array}{l}\text { Treatment group: Banks w/ turnovers } \\
(\text { TURN }=1 \text { ) }\end{array}$} & \multicolumn{2}{|c|}{ Significance } & \multicolumn{2}{|c|}{ Full sample } \\
\hline & $\mathrm{N}$ & Mean & Min & Max & S.D. & $\mathrm{N}$ & Mean & Min & Max & S.D. & Mean & Median & Mean & S.D. \\
\hline \multicolumn{15}{|l|}{ Matching variable } \\
\hline Total assets & 219 & 321,350 & 1,894 & $1,830,000$ & 562,641 & 59 & 364,897 & 16,215 & $6,163,741$ & 638,761 & 1 & 0 & 330,592 & 515,793 \\
\hline \multicolumn{15}{|l|}{ Risk variables } \\
\hline Z-Score & 219 & 80.7076 & 0.0102 & 515.5358 & 64.0194 & 59 & 39.9851 & 1.1837 & 224.7542 & 50.7527 & $4.8109^{* * *}$ & $16.8680^{* * *}$ & 72.0650 & 59.9700 \\
\hline Losses & 219 & -169 & $-13,581$ & 0 & 1,429 & 59 & $-1,478$ & $-28,330$ & 0 & 5,445 & $3.7337^{* * *}$ & $7.014^{* * *}$ & -446 & 2,446 \\
\hline $\begin{array}{l}\text { Losses (absolute value)/Total assets } \\
\text { Bank characteristics }\end{array}$ & 219 & 0.0006 & 0.0000 & 0.0494 & 0.0044 & 59 & 0.0066 & 0.0000 & 0.0932 & 0.0166 & $4.7657^{* * *}$ & $7.091^{* * *}$ & 0.0019 & 0.0089 \\
\hline Subordinated debt/Total assets & 219 & 0.0001 & 0.0000 & 0.0205 & 0.0018 & 59 & 0.0013 & 0.0000 & 0.0191 & 0.0042 & $3.3801^{* * *}$ & $8.1411^{* * *}$ & 0.0004 & 0.0023 \\
\hline BHC member & 219 & 0.6118 & 0.0000 & 1.0000 & 0.4780 & 59 & 0.6949 & 0.0000 & 1.0000 & 0.4310 & 1.1710 & 1.1700 & 0.6294 & 0.4838 \\
\hline Core deposits/Total assets & 219 & 0.0956 & 0.0016 & 0.9145 & 0.1468 & 59 & 0.0878 & 0.0021 & 0.4363 & 0.1419 & 0.3305 & 0.3442 & 0.0939 & 0.1590 \\
\hline Relative profits & 219 & -0.0019 & -0.0018 & 0.0015 & 0.0001 & 59 & -0.0011 & -0.0016 & 0.0089 & 0.0002 & 0.6358 & 2.1515 & -0.0024 & 0.0095 \\
\hline Return on equity & 219 & 0.0081 & -1.8150 & 0.1867 & 0.1841 & 59 & -0.0923 & -15.1506 & 8.9397 & 2.7688 & 0.6361 & 1.3770 & -0.0131 & 1.0766 \\
\hline SI dummy & 219 & 0.0593 & 0.0000 & 1.0000 & 0.2464 & 59 & 0.2372 & 0.0000 & 1.0000 & 0.4310 & $4.2106^{* * *}$ & $14.8122^{* * *}$ & 0.0971 & 0.2966 \\
\hline Dividend volatility (S.D.) & 155 & 613 & 0.00 & $10,317.95$ & $1,649.92$ & 42 & 513.65 & 0.00 & $5,439.95$ & $1,102.33$ & 0.37 & 0.50 & 594 & $1,543.92$ \\
\hline Dividend/equity volatility (S.D.) & 155 & 0.0128 & 0.0000 & 0.2721 & 0.0279 & 42 & 0.0124 & 0.0000 & 0.0858 & 0.0212 & 0.0765 & 0.4753 & 0.0150 & 0.0402 \\
\hline Dividend cut & 155 & 0.0129 & 0.0000 & 1.0000 & 0.1132 & 42 & 0.1190 & 0.0000 & 1.0000 & 0.3277 & $3.3736^{\star * *}$ & $3.288^{\star * *}$ & 0.0611 & 0.2400 \\
\hline
\end{tabular}

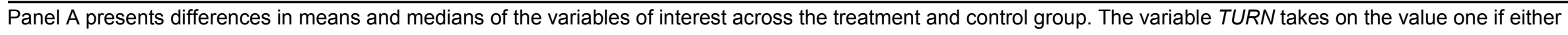
CEO, chairperson, president, CFO, or COO turnover is observed or zero otherwise. The variable Losses denotes the unscaled losses per bank in USD, and Losse

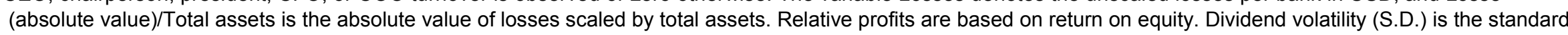
deviation of dividend payments in USD over eight quarters preceding the turnover. Dividend/equity volatility (S.D.) is the standard deviation of dividend payments scaled

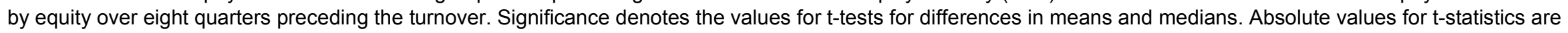
reported. ${ }^{* * *} p<0.01,{ }^{* *} p<0.05$, and ${ }^{*} p<0.1$. 


\begin{tabular}{|c|c|c|c|c|c|c|c|c|c|c|}
\hline Panel B & TURN & $\begin{array}{c}\text { Total } \\
\text { assets }\end{array}$ & Z-Score & $\begin{array}{c}\text { BHC } \\
\text { member }\end{array}$ & $\begin{array}{c}\text { Subordi- } \\
\text { nated debt/ } \\
\text { Total assets }\end{array}$ & $\begin{array}{c}\text { Core } \\
\text { deposits/ } \\
\text { Total } \\
\text { assets }\end{array}$ & $\begin{array}{c}\text { Losses } \\
\text { (Log) }\end{array}$ & $\begin{array}{l}\text { Relative } \\
\text { profits }\end{array}$ & SI dummy & $\begin{array}{c}\text { Dividend } \\
\text { cut }\end{array}$ \\
\hline Total assets & $\begin{array}{l}0.0527 \\
-0.4622\end{array}$ & 1 & & & & & & & & \\
\hline Z-Score & 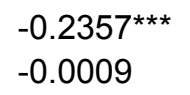 & $\begin{array}{l}0.0373 \\
-0.6024\end{array}$ & 1 & & & & & & & \\
\hline Subordinated debt/Total asset & $\begin{array}{l}0.2151^{* * *} \\
-0.0024\end{array}$ & $\begin{array}{l}0.0513 \\
-0.4744\end{array}$ & $\begin{array}{l}-0.1491^{* *} \\
-0.0366\end{array}$ & $\begin{array}{l}0.0617 \\
-0.3889\end{array}$ & 1 & & & & & \\
\hline Core deposits/Total assets & $\begin{array}{l}-0.0047 \\
-0.9474\end{array}$ & $\begin{array}{l}-0.1357^{*} \\
-0.0572\end{array}$ & $\begin{array}{l}0.1753^{* *} \\
-0.0137\end{array}$ & $\begin{array}{l}0.077 \\
-0.2821\end{array}$ & $\begin{array}{l}-0.0764 \\
-0.2858\end{array}$ & 1 & & & & \\
\hline Losses & $\begin{array}{l}0.3245^{\star * *} \\
0\end{array}$ & $\begin{array}{l}-0.0128 \\
-0.8583\end{array}$ & $\begin{array}{l}-0.3648^{* *} \\
0\end{array}$ & $\begin{array}{l}0.0071 \\
-0.9208\end{array}$ & $\begin{array}{l}0.1137 \\
-0.1116\end{array}$ & $\begin{array}{l}-0.2483^{* *} \\
-0.0004\end{array}$ & 1 & & & \\
\hline Dividend cut & $\begin{array}{l}0.2348^{* * *} \\
-0.0009\end{array}$ & $\begin{array}{l}-0.0215 \\
-0.7641\end{array}$ & $\begin{array}{l}-0.1699^{* *} \\
-0.017\end{array}$ & $\begin{array}{l}0.0201 \\
-0.7797\end{array}$ & $\begin{array}{l}0.1131 \\
-0.1135\end{array}$ & $\begin{array}{l}-0.0674 \\
-0.3466\end{array}$ & $\begin{array}{l}0.1046 \\
-0.1436\end{array}$ & $\begin{array}{l}0.0464 \\
-0.5169\end{array}$ & $\begin{array}{l}0.2078^{* * *} \\
-0.0034\end{array}$ & 1 \\
\hline Dividend volatility & $\begin{array}{l}-0.0263 \\
-0.7136 \\
\end{array}$ & $\begin{array}{l}0.4553^{* * *} \\
0\end{array}$ & $\begin{array}{l}0.0575 \\
-0.4225 \\
\end{array}$ & $\begin{array}{l}0.2535^{\star * *} \\
-0.0003 \\
\end{array}$ & $\begin{array}{r}-0.0607 \\
-0.3968 \\
\end{array}$ & $\begin{array}{l}0.0236 \\
-0.7425 \\
\end{array}$ & $\begin{array}{l}-0.1231 \\
-0.0847 \\
\end{array}$ & $\begin{array}{l}0.0309 \\
-0.6662 \\
\end{array}$ & $\begin{array}{r}-0.1137 \\
-0.1116 \\
\end{array}$ & $\begin{array}{l}-0.0246 \\
-0.7312 \\
\end{array}$ \\
\hline
\end{tabular}

Panel B presents correlation coefficients. Standard errors are in parentheses. ${ }^{* *} p<0.01,{ }^{* *} p<0.05$, and ${ }^{*} p<0.1$.

\begin{tabular}{lcc}
\hline Panel C & $\begin{array}{c}\text { Matching group: Banks w/o } \\
\text { managerial turnovers } \\
\text { (TURN }=\mathbf{0})\end{array}$ & $\begin{array}{c}\text { Treatment group: Banks wl } \\
\text { turnovers } \\
\text { (TURN = 1) }\end{array}$ \\
\hline Banks involved in mergers & 18 & 9 \\
$-\quad$ of which are acquirers & 8 & 4 \\
- of which are acquired & 10 & 5 \\
Banks that failed & 2 & 7 \\
\hline
\end{tabular}

Panel C reports information on bank status (mergers and failures) for treatment and control group. The variable TURN takes on the value one if an executive turnover is observed or zero otherwise. 
Table 2. Percentage Changes in Bank Performance Prior to Executive Turnover

\begin{tabular}{ccccc}
\hline Period & Z-Score & ROE & Relative ROE & Losses \\
\hline $\boldsymbol{t}$-1 & -0.0758 & -0.6263 & -0.0012 & 1.1801 \\
$\boldsymbol{t}-\mathbf{2}$ & -0.0364 & -0.4449 & -0.0009 & -0.0538 \\
$\boldsymbol{t}-3$ & -0.0823 & -0.2667 & -0.0002 & -0.1375 \\
\hline
\end{tabular}

Note. We report percentage changes in Z-Scores, ROE, relative ROE, and losses one, two, and three years prior to forced executive turnovers in the banks in our sample. 
Table 3. Conditional Logit Models for Different Sources of Discipline

\begin{tabular}{|c|c|c|c|c|c|c|c|}
\hline & $\begin{array}{c}1) \\
\text { Forced }\end{array}$ & $\begin{array}{c}(2) \\
\text { Forced }\end{array}$ & $\begin{array}{c}(3) \\
\text { Forced }\end{array}$ & $\begin{array}{c}(4) \\
\text { Forced }\end{array}$ & $\begin{array}{c}(5) \\
\text { Forced }\end{array}$ & $\begin{array}{c}6) \\
\text { Odds }\end{array}$ & $\begin{array}{c}(7) \\
\text { Voluntary }\end{array}$ \\
\hline & Turnover & Turnover & Turnover & Turnover & Turnover & & Turnover \\
\hline \multirow[t]{2}{*}{$\bar{T}$ Total assets $(\log )$} & 1.0545 & 1.0305 & 0.7338 & 0.8965 & 0.5938 & & 2.9941 \\
\hline & -0.6075 & -0.3421 & -0.2381 & -0.2947 & -0.1923 & & -0.6579 \\
\hline \multirow[t]{2}{*}{ Z-Score } & $-0.0150^{* * *}$ & $-0.0090^{*}$ & $-0.0290^{* *}$ & $-0.0093^{*}$ & $-0.0298^{* *}$ & $0.1932^{* *}$ & 0.0143 \\
\hline & $(-3.2194)$ & $(-1.8105)$ & $(-1.9682)$ & $(-1.8615)$ & $(-1.9740)$ & & -1.2347 \\
\hline \multirow[t]{2}{*}{ Losses (log) } & $0.2278^{* *}$ & $0.3084^{* *}$ & $0.3256^{* *}$ & $0.3512^{* * *}$ & $0.3976^{* *}$ & $2.4174^{* *}$ & 0.095 \\
\hline & -2.4416 & -2.4581 & -2.2427 & -2.6086 & -2.514 & & -0.4062 \\
\hline \multirow[t]{2}{*}{ Subordinated debt/Total assets } & $0.1494^{* *}$ & $0.1866^{* *}$ & 0.1241 & $0.2104^{* *}$ & 0.1383 & & 23.0354 \\
\hline & -2.0633 & -2.3121 & -0.9979 & -2.4503 & -1.0821 & & -0.2289 \\
\hline \multirow[t]{2}{*}{ Core deposits/Total assets } & 1.4079 & $3.8737^{* *}$ & $4.2124^{* *}$ & $4.0469^{* *}$ & $4.4932^{* *}$ & $1.7197^{* *}$ & 1.6015 \\
\hline & -1.2044 & -2.0244 & -2.0716 & -2.0702 & -2.1051 & & -0.656 \\
\hline \multirow[t]{2}{*}{ BHC member } & 0.384 & 0.0687 & -0.1109 & 0.1418 & -0.0049 & & -0.5039 \\
\hline & -0.9763 & -0.129 & $(-0.1846)$ & -0.2589 & $(-0.0079)$ & & $(-0.7360)$ \\
\hline \multirow{2}{*}{ Relative profits } & -0.0003 & -0.0004 & 0.0152 & -0.0006 & 0.018 & & -0.0259 \\
\hline & $(-0.2500)$ & $(-0.2648)$ & -0.8772 & $(-0.4060)$ & -1.0343 & & $(-1.2038)$ \\
\hline \multirow[t]{2}{*}{ Dividend volatility } & & -0.0003 & -0.0003 & -0.0003 & -0.0003 & & 0.0001 \\
\hline & & $(-1.5643)$ & $(-1.3640)$ & $(-1.5610)$ & $(-1.3647)$ & & -0.2463 \\
\hline \multirow{2}{*}{ Dividend cut } & & $2.6504^{*}$ & $2.4584^{*}$ & $3.1170^{* *}$ & $3.0638^{* *}$ & $12.288^{* *}$ & -17.5939 \\
\hline & & -1.9005 & -1.7791 & -2.0952 & -2.0158 & & $(-0.0039)$ \\
\hline \multirow[t]{2}{*}{ Total assets $(\log ){ }^{*} Z$-Score } & & & $0.0140^{*}$ & & $0.0141^{*}$ & $4.4534^{*}$ & $-0.0248^{* *}$ \\
\hline & & & -1.7429 & & -1.7111 & & $(-2.4145)$ \\
\hline \multirow[t]{2}{*}{ BHC member * Z-Score } & & & -0.0029 & & -0.0028 & & 0.0223 \\
\hline & & & $(-0.2737)$ & & $(-0.2500)$ & & -1.1109 \\
\hline \multirow[t]{2}{*}{ Subordinated debt/Total assets * Z-Score } & & & -3.8245 & & -5.0082 & & 1.3515 \\
\hline & & & $(-0.7473)$ & & $(-0.9088)$ & & -0.4142 \\
\hline \multirow[t]{2}{*}{ Core deposits/Total assets ${ }^{*} \mathrm{Z}$-Score } & & & -0.0254 & & -0.0316 & & 0.0736 \\
\hline & & & $(-0.6057)$ & & $(-0.7272)$ & & -1.4365 \\
\hline \multirow[t]{2}{*}{ Relative profits * Z-Score } & & & 0.0002 & & 0.0003 & & -0.0003 \\
\hline & & & -0.9339 & & -1.1166 & & $(-0.6705)$ \\
\hline \multirow[t]{2}{*}{ SI dummy } & & & & -1.0093 & -1.2873 & & 63.5373 \\
\hline & & & & $(-1.0963)$ & $(-0.3909)$ & & -0.0002 \\
\hline \multirow[t]{2}{*}{ SI dummy * Z-Score } & & & & & 0.0072 & & 2.2212 \\
\hline & & & & & -0.1136 & & -0.0003 \\
\hline Observations & 278 & 197 & 197 & 197 & 197 & & 137 \\
\hline Number of turnovers & 59 & 42 & 42 & 42 & 42 & & 32 \\
\hline Number of turnovers predicted correctly & 30 & 24 & 26 & 25 & 31 & & 18 \\
\hline Type I error & 0.33 & 0.29 & 0.19 & 0.28 & 0.23 & & 0.22 \\
\hline Type II error & 0.16 & 0.14 & 0.12 & 0.14 & 0.11 & & 0.15 \\
\hline LR Statistic & $44.33^{* * *}$ & $40.61^{* * *}$ & $50.20^{\star \star *}$ & $41.89^{\star * *}$ & $52.60^{* * *}$ & & $30.02^{* *}$ \\
\hline Pseudo R-squared & 0.2466 & 0.3175 & 0.3925 & 0.3275 & 0.4113 & & 0.334 \\
\hline
\end{tabular}


Table 4. Key Variables of Interest by Percentile of Z-Score

\begin{tabular}{ccccccc}
\hline Decile/Quartile & $\mathrm{N}$ & Z-Score & Losses (log) & ROE & $\begin{array}{c}\text { Predicted } \\
\text { Turnovers }\end{array}$ & $\begin{array}{c}\text { Actual } \\
\text { Turnovers }\end{array}$ \\
\hline 5 & 10 & 2.2964 & 5.4245 & -1.6432 & 6 & 6 \\
10 & 9 & 8.9913 & 3.4715 & 0.0293 & 5 & 5 \\
25 & 31 & 17.5971 & 1.3089 & 0.0143 & 8 & 7 \\
50 & 48 & 42.7133 & 0.6395 & 0.0218 & 3 & 3 \\
75 & 49 & 88.2115 & 0 & 0.0297 & 0 & 5 \\
90 & 31 & 126.2724 & 0 & 0.0322 & 0 & 13 \\
95 & 9 & 181.2672 & 0 & 0.0267 & 0 & 1 \\
100 & 10 & 231.2051 & 0 & 0.0309 & 1 \\
\hline
\end{tabular}

Spearman's rank order correlation between predicted turnovers and realized values of the

We report t-tests for differences in means and medians for Z-Scores, ROE, relative profits, and losses for the turnover banks for one, two and three years following the turnover. Absolute values of test statistics are presented. ${ }^{* * *} p<0.01,{ }^{* *} p<0.05,{ }^{*} p<0.1$. 
Table 5. Changes in Bank Performance After Executive Turnovers (Treatment Group)

\begin{tabular}{|c|c|c|c|c|c|c|c|c|c|c|}
\hline & to & $t+1$ & Mean & Median & $t+2$ & Mean & Median & $t+3$ & Mean & Median \\
\hline Z-Score & 39.98 & 51.0749 & 0.6475 & 0.2026 & 48.0386 & 0.2762 & 0.2903 & 53.4393 & $1.7316^{*}$ & $3.9032^{* *}$ \\
\hline ROE & -0.0923 & -0.0796 & 0.0586 & 0.6574 & 0.0192 & 0.3177 & 0.8065 & 0.0139 & 0.3632 & 0.8065 \\
\hline Relative ROE & -0.008 & -0.0107 & $2.3319^{* *}$ & $3.5831^{*}$ & -0.0008 & $3.0232^{* * *}$ & $3.9032^{* *}$ & -0.0014 & $2.6634^{* * *}$ & $7.2581^{* * *}$ \\
\hline Losses & -1478.153 & -256.0571 & $2.0337^{\star *}$ & $2.895^{\star \star \star}$ & -41 & $2.3538^{\star *}$ & $4.181^{\star \star \star}$ & -147.7931 & $2.3073^{\star \star}$ & $3.576^{\star \star \star}$ \\
\hline
\end{tabular}

We report t-tests for differences in means and medians for Z-Scores, ROE, relative profits, and losses for the turnover banks for one, two and three years following the turnover. Absolute values of test statistics are presented. ${ }^{* * *} p<0.01,{ }^{* *} p<0.05,{ }^{*} p<0.1$. 
Table 6. Changes in Bank Performance After Executive Turnovers (Treatment and Control Group)

\begin{tabular}{|c|c|c|c|c|c|c|c|c|c|c|c|}
\hline & \multicolumn{3}{|c|}{$t+1$} & \multirow[b]{2}{*}{ Median } & \multicolumn{4}{|c|}{$t+2$} & \multicolumn{3}{|c|}{$t+3$} \\
\hline & Treat-ment & $\begin{array}{l}\text { Control } \\
\text { group }\end{array}$ & Mean & & $\overline{\text { Treat-ment }}$ & $\begin{array}{l}\text { Control } \\
\text { group }\end{array}$ & Mean & Median & $\begin{array}{c}\text { Control } \\
\text { group }\end{array}$ & Mean & Median \\
\hline Z-Score & 51.0749 & 86.0522 & $2.8103^{* * *}$ & $8.1461^{* * *}$ & 48.0386 & 87.9620 & $3.0228^{* * *}$ & $6.3352^{* *}$ & 92.0063 & $2.5505^{* *}$ & $7.5699^{* * *}$ \\
\hline Relative Profits & -0.0107 & -0.0030 & 1.1074 & 0.3258 & -0.0008 & -0.0012 & 0.3265 & 0.0237 & -0.0008 & 0.6117 & 0.4031 \\
\hline Losses & 256.0571 & 129.7176 & 0.8426 & 1.0997 & 41.0000 & 111.5424 & 0.9674 & 0.0016 & 393.8144 & 0.5844 & 2.6038 \\
\hline
\end{tabular}

We report t-tests for differences in means and medians for Z-Scores, ROE, relative profits, and losses for the turnover banks and the corresponding control group for one, two and three years following the turnover. Absolute values of test statistics are presented. ${ }^{* * *} p<0.01$, ${ }^{* *} p<0.05,{ }^{*} p<0.1$. 
Table 7. Changes in Bank Performance After Executive Turnovers (Matching on Propensity Scores, Treatment and Control Group)

\begin{tabular}{|c|c|c|c|c|c|c|c|c|c|c|c|c|}
\hline Matching model & (1) & (2) & (3) & (4) & (5) & (6) & (7) & (8) & (9) & (10) & (11) & (12) \\
\hline Period & $t+1$ & $T+2$ & $t+3$ & $t+1$ & $t+2$ & $t+3$ & $t+1$ & $t+2$ & $t+3$ & $t+1$ & $t+2$ & $t+3$ \\
\hline Dependent variable & Z-Score & Z-Score & Z-Score & $R O E$ & $R O E$ & $R O E$ & Rel. ROE & Rel. ROE & Rel. ROE & Losses & Losses & Losses \\
\hline $\begin{array}{l}\text { Banks with forced } \\
\text { turnovers vs. those } \\
\text { that do not }\end{array}$ & $-32.519^{\star \star \star}$ & $-42.506^{\star \star \star}$ & $-37.981^{* * *}$ & -82.746 & 8.147 & -10.559 & -0.082 & 0.009 & -0.010 & 163.450 & -78.303 & -72.853 \\
\hline z-statistic & -3.01 & -4.15 & -2.93 & -1.07 & -0.6 & -1.46 & -1.06 & -0.64 & -1.44 & -1.24 & -1.37 & -0.26 \\
\hline Observations & 166 & 151 & 126 & 166 & 151 & 126 & 166 & 151 & 126 & 166 & 151 & 126 \\
\hline
\end{tabular}

The treatment effects provide information about mean differences for risk measured by Z-Scores in Columns 1-3, for mean differences in ROE (Columns 4-6, for mean differences in relative ROE in Columns 7-9, and for mean differences of losses in Columns 10-12 between banks that experienced a forced turnover of an executive and those that did not experience a forced turnover. We estimate these propensity scores using total assets (log), BHC member, subordinated debt/total assets, core deposits/total assets, relative profits, dividend volatility, and dividend cuts as covariates. Results are based on 4 matches. Absolute values of $z$-statistics are presented in parentheses. ${ }^{* *} p<0.01,{ }^{* *} p<0.05,{ }^{*} p<0.1$. 


\section{ApPEndiX I. MEASURING BANK SOUNDNESS Using THE Z-ScORE}

The Z-Score is a frequently used measure of bank soundness (e.g., Mercieca, Schaeck, and Wolfe, 2007; Stiroh, 2004a, 2004b; Demirgüç-Kunt, Detragiache, and Tressel, 2008). A number of reasons exist for the Z-Score's popularity as a measure of bank soundness.

First, it can be shown that the Z-Score is inversely related to the probability of a financial institution's insolvency, i.e. the probability that the value of its assets falls below the value of its debt. The probability of default is given by $p(R O A<E / A)=\int_{-\infty}^{E / A} \phi(R O A) d R O A$. If ROA is normally distributed, then $p(R O A<E / A)=\int_{-\infty}^{z} N(0,1) d R O A$, where $\mathrm{z}$ is the Z-Score. In other words, if returns are normally distributed, the Z-Score measures the number of standard deviations a return realization has to fall in order to deplete equity. Even if $\mu$ is not normally distributed, $\mathrm{z}$ is the lower bound on the probability of default (by Tchebycheff inequality).

Second, an important practical advantage of the Z-Score is that it can be computed in an easy and transparent fashion for all banks in the sample as only accounting information is needed (in contrast, market-based measures such as distance to default require markets that are non-existent or illiquid for many of the banks in our sample).

Third, empirical studies confirm that the Z-Score is indeed a useful measure of bank soundness. For example, Čihák (2007), using a sample of 29 countries, including 12 with systemic banking crises, finds that banks in these crises are characterized by significantly lower Z-Scores than other banks.

Fourth, the Z-Score, although it not explicitly incorporates an institution's exposure to individual products such as CDOs, CDs, or subprime mortgages, ultimately reflects such exposures in case these risks come to bite and translate into either lower returns, lower capitalization, or higher standard deviations of returns. 


\section{APPENDIX II. OVERVIEW OF DATA AND SOURCES}

Newspaper sources used: The Financial Times, New York Times, Wall Street Journal, American Banker, Forbes, BBC News, Business Week, SEC Info, Investor's Business Daily, Business Wire, The Daily Record (Baltimore, Maryland), Orange County Register (California), The Herald (Rock

Hill, South Carolina), Herald Tribune, Sarasota Herald-Tribune (Florida), Charlotte Observer (North Carolina), Columbus Dispatch, Virginia Lawyers Weekly, The Associated Press, Bangor Daily News (Maine), Arkansas Business, Patriot Ledger (Quincy, MA), Baltimore Business Journal, Sacramento Business Journal (California), Philadelphia Business Journal, The Philadelphia Inquirer, Birmingham News (Alabama), Los Angeles Times, Charleston Gazette (West Virginia), Florida Times-Union (Jacksonville, FL), Milwaukee Journal Sentinel (Wisconsin), Wisconsin State Journal (Madison, WI), Miami Herald, The Seattle Times, Plain Dealer (Cleveland, Ohio), Star Tribune (Minneapolis, MN), The Post-Standard (Syracuse, NY), Knight-Ridder/Tribune Business News, The Salina Journal (Kansas), The Providence Journal (Rhode Island), Kansas City Star, The Press Enterprise Co, The Indianapolis Star, New Hampshire Business Review, Black Enterprise, Business Services Industry, Crain's Detroit Business, Kansas City Business Journal, Dallas Business Journal, Hartford Courant (Connecticut), Buffalo News (New York), Washington Post, Fairfield County Business Journal, San Francisco Business Times, Rochester Business Journal, St. Petersburg Times (Florida), United Press International, The Atlanta Journal and Constitution, National Mortgage News, The Times Union (Albany, NY), Intelligencer Journal, St. Louis Post-Dispatch (Missouri), New Haven Register, Arkansas Democrat-Gazette (Little Rock), The Honolulu Advertiser (Honolulu, HI), The Record (Bergen County, NJ), The Post-Standard (Syracuse, NY), Omaha World Herald (Nebraska), Times-Picayune (New Orleans, LA), Des Moines Register, The Washington Post and Bnet, The Commercial Appeal (Memphis, TN), Hawaii Inc., PR Newswire, The Augusta Chronicle (Georgia), News \& Record (Greensboro, NC), St Louis Business Journal, The Lexington Herald Leader (Kentucky), The Business Journal (Tampa Bay Florida), East Bay Business Times (California), Columbus Business First (Ohio), The Business Review (Albany New York), Denver Business Journal, Las Vegas Review-Journal, The State (Columbia, SC), The Houston Chronicle (Texas), Lancaster New Era (Lancaster, PA.), El Paso Times (El Paso, Texas), Providence JournalBulletin (Rhode Island), St. Louis Post-Dispatch (Missouri), Rocky Mountain News (Denver, Colorado), Atlanta Business Chronicle, The Wichita Eagle, The Tennessean, Winston-Salem Journal, Florida Trend, The Seattle Post-Intelligencer, La Crosse Tribune (Wisconsin), The Capital Times (Madison, WI), The Journal News, Morning Call (Allentown, PA), The Associated Press State \& Local Wire, The Boston Herald, Columbus Ledger-Enquirer, The Baltimore Sun, The Olympian (Olympia, Washington), Dayton Daily News (Ohio), The Bradenton Herald, Vermont Business Magazine, The Boston Globe, Knoxville News-Sentinel (Tennessee), Business FirstBuffalo, Chicago Tribune, Seattleite and Puget Sound Business Journal, San Diego Daily Transcript, The Herald-Sun - Durham, North Carolina, The Dallas Morning News, Cox News Service, The Pantograph (Bloomington, IL), Business for Central New Jersey, The Business Journal-San Jose, Facts on File World News Digest, Citigroup Inc.CNNMoney.com 
ApPendix III. TuRnOVERs In SMALL AND MEDIUM Sized U.S. BANKS 1990-2007

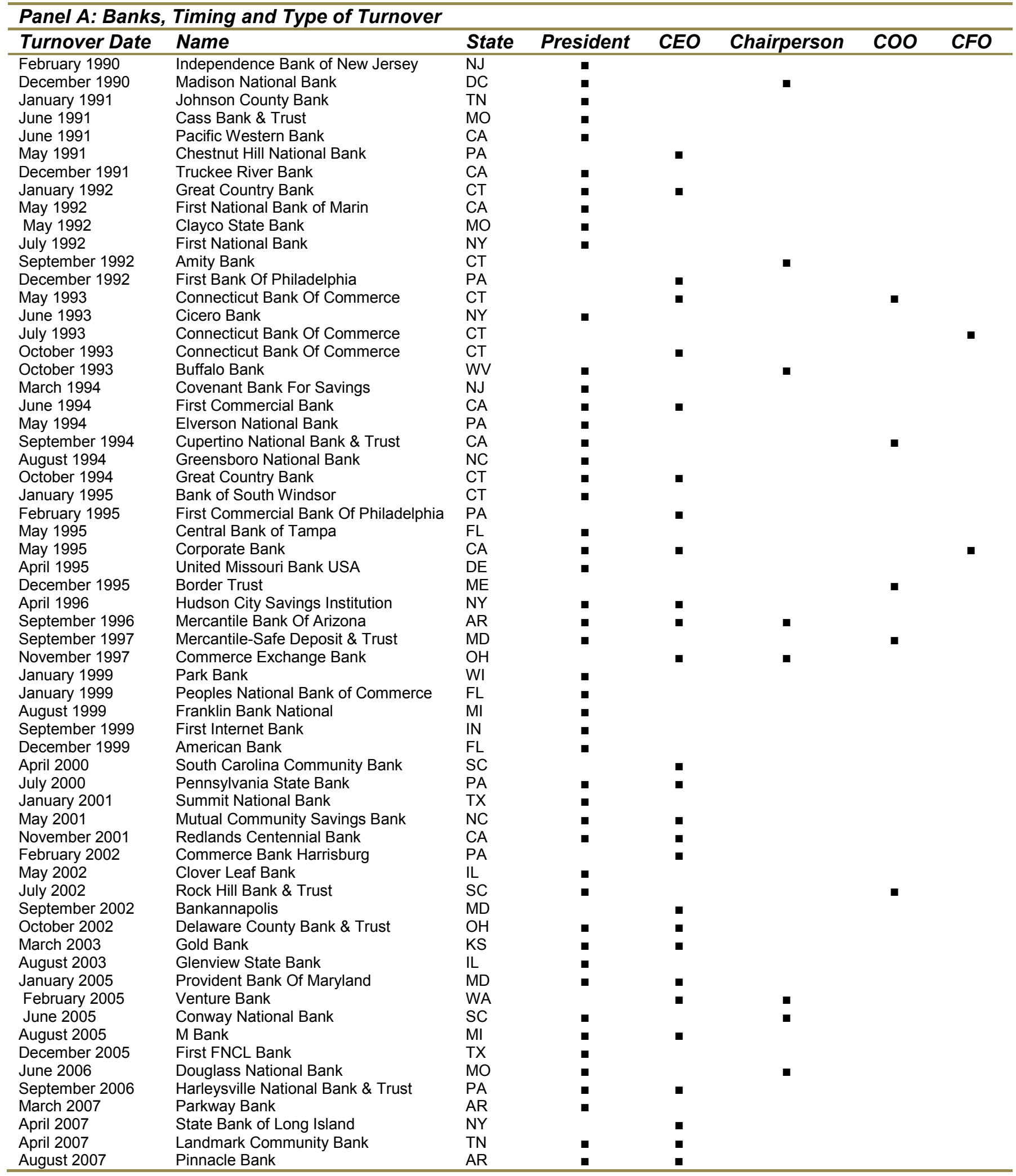




\begin{tabular}{cc}
\hline \multicolumn{2}{c}{ Panel B: Distribution of Executive Tturnovers } \\
1990-2007 \\
\hline Number of Turnovers \\
\hline 1990 & 3 \\
1991 & 5 \\
1992 & 7 \\
1993 & 7 \\
1994 & 9 \\
1995 & 8 \\
1996 & 5 \\
1997 & 4 \\
1998 & 0 \\
1999 & 5 \\
2000 & 3 \\
2001 & 5 \\
2002 & 7 \\
2003 & 3 \\
2004 & 0 \\
2005 & 9 \\
2006 & 4 \\
2007 & 6 \\
\hline
\end{tabular}




\section{APPENDIX IV. RoBUSTNESS CHECKS}

To assess the robustness of our results, we use alternative definitions of bank executives, alternative estimation methods, an alternative number of matched banks, and alternative sample selections in Table A. We also extend our analysis to consider corporate control activity (mergers and acquisitions) around the forced departure of a bank executive (i.e., between $t-1$ and $t+1$ years), and we also account for the effect of closely held/concentrated ownership. In a further test, we adjust the Z-Score for outliers and examine if an alternative measurement of losses affects our inferences. For brevity, we constrain our discussion to key results, and highlight differences with the results presented in Table 3.

In Column 1 of Table A, we exclusively focus on "top executives", defined as president, chairperson, or CEO, excluding turnovers of CFOs and COOs. Our results remain largely unaffected. We conclude that the definition of a bank executive is not driving the results.

In Column 2, we remove banks that fail during the sampling period to control for cases where the bank manager may have left the institution before problems become visible. This specification leaves the association of bank risk with executive turnover unchanged, while rendering the coefficient on the loss variable insignificant. These results are not surprising, given that most of the failures take place several years after a forced turnover is observed.

We examine in Column 3 whether executive turnovers are related to corporate control activity rather than market discipline (e.g., Denis and Serano, 1996; Denis, Denis, and Sarin, 1997; Kini, Kracaw, and Mian, 2004; Harford and Li, 2007). The idea is that an executive turnover may reflect an interaction between external control activity and internal monitoring, rather than a disciplining action attributable to excessive bank risk-taking. The intuition is that an executive turnover could serve as a signal for takeover bids (e.g., Jensen, 1988). ${ }^{29}$ Using the National Information Center's website facility to retrieve information about the bank's history, we investigate if banks were involved in M\&A activities during a one-year time window surrounding the executive's departure date and remove these institutions from our sample. We find that nine institutions with turnovers were also involved in a merger and 18 banks in the control group were actively involved in M\&A activities. When excluding these institutions, the finding that forced turnovers are consistently associated with bank risk remains valid. In unreported regressions, we further differentiate between acquirer and target and obtain qualitatively identical findings.

\footnotetext{
${ }^{29}$ Note that the corporate takeover market can be considered as a "court of last resort" in the sense that it constitutes a source of external discipline that is invoked in instances when internal control mechanisms are relatively weak or ineffective (Jensen, 1988).
} 
TABLE A. ROBUSTNESS CHECKS

\begin{tabular}{|c|c|c|c|c|c|c|c|}
\hline Specification & $\begin{array}{c}\text { (1) } \\
\text { Top } \\
\text { executives }\end{array}$ & $\begin{array}{c}(2) \\
\text { Failures } \\
\text { removed }\end{array}$ & $\begin{array}{c}(3) \\
\text { Mergers } \\
\text { removed }\end{array}$ & $\begin{array}{c}(4) \\
\text { S- } \\
\text { Corporatio } \\
n\end{array}$ & $\begin{array}{c}\text { (5) } \\
\text { Eight } \\
\text { Matches }\end{array}$ & $\begin{array}{l}(6) \\
\text { Winsorized } \\
\text { Z-score } \\
\text { and } 4 \\
\text { periods of } \\
\text { losses }\end{array}$ & $\begin{array}{c}(7) \\
\text { Ordered } \\
\text { Logit }\end{array}$ \\
\hline Total assets $(\log )$ & $\begin{array}{c}0.5938 \\
(0.1923)\end{array}$ & $\begin{array}{c}-0.1945 \\
(-0.0616)\end{array}$ & $\begin{array}{c}7.7298 \\
(1.3593)\end{array}$ & $\begin{array}{c}0.4633 \\
(0.1509)\end{array}$ & $\begin{array}{c}2.2111 \\
(0.7014)\end{array}$ & $\begin{array}{c}1.8424 \\
(0.6404)\end{array}$ & $\begin{array}{c}0.1439 \\
(0.4033)\end{array}$ \\
\hline Z-Score & $\begin{array}{l}-0.0298^{* *} \\
(-1.9740)\end{array}$ & $\begin{array}{c}-0.0277^{*} \\
(-1.7710)\end{array}$ & $\begin{array}{l}-0.0388^{*} \\
(-1.8837)\end{array}$ & $\begin{array}{l}-0.0267^{*} \\
(-1.6697)\end{array}$ & $\begin{array}{c}-0.0281^{*} \\
(-1.8796)\end{array}$ & $\begin{array}{l}-0.0275^{\star} \\
(-1.7115)\end{array}$ & $\begin{array}{c}-0.0314^{\star *} \\
(-2.5463)\end{array}$ \\
\hline Losses (log) & $\begin{array}{l}0.3976^{* \star} \\
(2.5140)\end{array}$ & $\begin{array}{c}0.2718 \\
(1.2984)\end{array}$ & $\begin{array}{c}0.2741 \\
(1.2553)\end{array}$ & $\begin{array}{l}0.4121^{* *} \\
(2.5642)\end{array}$ & $\begin{array}{c}0.4321^{* * *} \\
(2.7717)\end{array}$ & $\begin{array}{l}0.1938^{* *} \\
(2.1051)\end{array}$ & $\begin{array}{l}0.3407^{* *} \\
(2.3689)\end{array}$ \\
\hline Subordinated debt/Total assets & $\begin{array}{c}0.1383 \\
(1.0821)\end{array}$ & $\begin{array}{c}0.2212 \\
(1.5764)\end{array}$ & $\begin{array}{c}0.3929 \\
(1.2243)\end{array}$ & $\begin{array}{c}0.1394 \\
(1.0828)\end{array}$ & $\begin{array}{c}0.1642 \\
(1.2840)\end{array}$ & $\begin{array}{c}0.4355 \\
(0.1969)\end{array}$ & $\begin{array}{c}0.0839 \\
(0.7375)\end{array}$ \\
\hline Core deposits/Total assets & $\begin{array}{l}4.4932^{* \star} \\
(2.1051)\end{array}$ & $\begin{array}{l}4.7615^{\star *} \\
(2.1357)\end{array}$ & $\begin{array}{c}7.7313^{\star *} \\
(2.2488)\end{array}$ & $\begin{array}{l}4.8117^{\star *} \\
(2.1658)\end{array}$ & $\begin{array}{c}3.5673^{*} \\
(1.8511)\end{array}$ & $\begin{array}{c}3.9300^{*} \\
(1.6520)\end{array}$ & $\begin{array}{c}3.1572^{*} \\
(1.9387)\end{array}$ \\
\hline $\mathrm{BHC}$ member & $\begin{array}{c}-0.0049 \\
(-0.0079)\end{array}$ & $\begin{array}{c}0.1469 \\
(0.2283)\end{array}$ & $\begin{array}{c}0.6322 \\
(0.8256)\end{array}$ & $\begin{array}{c}-0.0620 \\
(-0.0984)\end{array}$ & $\begin{array}{c}0.1713 \\
(0.2861)\end{array}$ & $\begin{array}{c}-0.0563 \\
(-0.0825)\end{array}$ & $\begin{array}{c}0.6219 \\
(1.0874)\end{array}$ \\
\hline Relative profits & $\begin{array}{c}0.0180 \\
(1.0343)\end{array}$ & $\begin{array}{c}0.0103 \\
(0.5552)\end{array}$ & $\begin{array}{c}-0.0192 \\
(-0.6516)\end{array}$ & $\begin{array}{c}0.0197 \\
(1.1437)\end{array}$ & $\begin{array}{c}0.0232 \\
(1.3490)\end{array}$ & $\begin{array}{c}0.0152 \\
(0.7524)\end{array}$ & $\begin{array}{c}0.0063 \\
(0.3724)\end{array}$ \\
\hline Dividend volatility & $\begin{array}{c}-0.0003 \\
(-1.3647)\end{array}$ & $\begin{array}{c}-0.0003 \\
(-1.3319)\end{array}$ & $\begin{array}{l}-0.0006^{* *} \\
(-2.0758)\end{array}$ & $\begin{array}{c}-0.0003 \\
(-1.4230)\end{array}$ & $\begin{array}{c}-0.0003 \\
(-1.3313)\end{array}$ & $\begin{array}{c}-0.0003 \\
(-1.4826)\end{array}$ & $\begin{array}{c}0.0001 \\
(1.0216)\end{array}$ \\
\hline Dividend cut & $\begin{array}{l}3.0638^{* *} \\
(2.0158)\end{array}$ & $\begin{array}{l}3.4878^{\star \star} \\
(2.1763)\end{array}$ & $\begin{array}{l}81.1898 \\
(0.0048)\end{array}$ & $\begin{array}{l}3.0553^{* \star} \\
(2.0111)\end{array}$ & $\begin{array}{l}3.0168^{*} \\
(1.8452)\end{array}$ & $\begin{array}{l}3.3411^{* *} \\
(2.0083)\end{array}$ & $\begin{array}{c}1.5262 \\
(1.5396)\end{array}$ \\
\hline S-Corporation & & & & $\begin{array}{l}-15.5618 \\
(-0.0066)\end{array}$ & & & \\
\hline Total assets $(\log ){ }^{*} Z$-Score & $\begin{array}{c}0.0141^{*} \\
(1.7111)\end{array}$ & $\begin{array}{c}0.0120 \\
(1.4474)\end{array}$ & $\begin{array}{l}0.0245^{* *} \\
(1.9951)\end{array}$ & $\begin{array}{c}0.0130 \\
(1.5131)\end{array}$ & $\begin{array}{c}0.0135^{*} \\
(1.6706)\end{array}$ & $\begin{array}{l}0.0163^{* *} \\
(1.9767)\end{array}$ & $\begin{array}{c}0.0192^{* * *} \\
(2.8459)\end{array}$ \\
\hline BHC member * Z-Score & $\begin{array}{c}-0.0028 \\
(-0.2500)\end{array}$ & $\begin{array}{c}-0.0032 \\
(-0.2810)\end{array}$ & $\begin{array}{c}-0.0079 \\
(-0.5622)\end{array}$ & $\begin{array}{c}-0.0034 \\
(-0.3071)\end{array}$ & $\begin{array}{c}-0.0046 \\
(-0.4325)\end{array}$ & $\begin{array}{c}-0.0071 \\
(-0.6320)\end{array}$ & $\begin{array}{c}-0.0055 \\
(-0.5149)\end{array}$ \\
\hline $\begin{array}{l}\text { Subordinated debt/Total assets * Z- } \\
\text { Score }\end{array}$ & -5.0082 & 0.8009 & -3.8608 & -5.0604 & -0.8689 & -4.1961 & -2.2226 \\
\hline & $(-0.9088)$ & $(0.1362)$ & $(-0.3085)$ & $(-0.9194)$ & $(-0.2196)$ & $(-0.6873)$ & $(-0.6883)$ \\
\hline Core deposits/Total assets * Z-Score & $\begin{array}{c}-0.0316 \\
(-0.7272)\end{array}$ & $\begin{array}{c}-0.0448 \\
(-0.9801)\end{array}$ & $\begin{array}{c}-0.0118 \\
(-0.2159)\end{array}$ & $\begin{array}{c}-0.0308 \\
(-0.6819)\end{array}$ & $\begin{array}{l}-0.0323 \\
(-0.7772)\end{array}$ & $\begin{array}{c}-0.0046 \\
(-0.1142)\end{array}$ & $\begin{array}{c}0.0067 \\
(0.2268)\end{array}$ \\
\hline Relative profits * Z-Scores & $\begin{array}{c}0.0003 \\
(1.1166)\end{array}$ & $\begin{array}{l}0.0004 \\
(1.0249)\end{array}$ & $\begin{array}{c}-0.0002 \\
(-0.3870)\end{array}$ & $\begin{array}{c}0.0003 \\
(1.2264)\end{array}$ & $\begin{array}{l}0.0004 \\
(1.3584)\end{array}$ & $\begin{array}{c}0.0002 \\
(0.8856)\end{array}$ & $\begin{array}{c}0.0001 \\
(0.3720)\end{array}$ \\
\hline SI dummy & $\begin{array}{c}-1.2873 \\
(-0.3909)\end{array}$ & $\begin{array}{c}-0.5143 \\
(-0.2046)\end{array}$ & $\begin{array}{l}-97.4733 \\
(-0.8851)\end{array}$ & $\begin{array}{c}-1.1854 \\
(-0.3634)\end{array}$ & $\begin{array}{l}-3.3363 \\
(-0.8703)\end{array}$ & $\begin{array}{c}-1.1161 \\
(-0.2458)\end{array}$ & $\begin{array}{l}-1.3745 \\
(-0.7963)\end{array}$ \\
\hline SI dummy * Z-Score & $\begin{array}{l}0.0072 \\
(0.11)\end{array}$ & $\begin{array}{c}0.0511 \\
(0.88)\end{array}$ & $\begin{array}{c}-1.6829 \\
(-0.88)\end{array}$ & $\begin{array}{c}0.0092 \\
(0.1453)\end{array}$ & $\begin{array}{c}-0.0391 \\
(-0.55)\end{array}$ & $\begin{array}{c}0.0005 \\
(0.0074)\end{array}$ & $\begin{array}{c}-0.0146 \\
(-0.61)\end{array}$ \\
\hline Observations & 192 & 169 & 155 & 197 & 213 & 196 & 203 \\
\hline Number of turnovers & 41 & 36 & 35 & 42 & 42 & 42 & $\mathrm{n} / \mathrm{a}$ \\
\hline $\begin{array}{l}\text { Number of turnovers predicted } \\
\text { correctly }\end{array}$ & 30 & 25 & 30 & 32 & 30 & 25 & $\mathrm{n} / \mathrm{a}$ \\
\hline Type I error & 0.23 & 0.30 & 0.23 & 0.22 & 0.30 & 0.20 & $\mathrm{n} / \mathrm{a}$ \\
\hline Type II error & 0.11 & 0.12 & 0.10 & 0.10 & 0.11 & 0.13 & $\mathrm{n} / \mathrm{a}$ \\
\hline LR Statistic & $49.38^{* * *}$ & $38.65^{\star \star *}$ & $52.74^{\star \star *}$ & $54.28^{\star \star *}$ & $52.63^{\star \star \star}$ & $49.73^{\star * *}$ & $132.15^{\star \star \star}$ \\
\hline Pseudo R-squared & 0.3961 & 0.3514 & 0.5165 & 0.4244 & 0.3962 & 0.3901 & 0.2006 \\
\hline
\end{tabular}

The dependent variable TURN takes on the value one if either CEO, chairperson, president, CFO, or COO turnover is observed or zero otherwise in Columns $1-4$. Column 1 constrains the analysis to top executives (CEOs, presidents, chairpersons) only. In Column 2 we remove banks that fail from the sample, whereas Column 3 adjusts the regression for bank mergers by removing banks that are involved in M\&A activities during a one-year time window. In Column 4, we account for closely held/concentrated ownership and include a dummy variable for S-Corporations. Column 5 uses a maximum of eight rather than four matched banks, and Column 6 uses a winsorized Z-Score (at the $0.5^{\text {th }}$ and $99.5^{\text {th }}$ percentile) and measures losses (log) over the past 4 periods. Column 7 uses an ordered logit model where the dependent variable ranges from zero to 3 . The dependent variable sums across the different turnovers. The loss variable is defined as the log of the absolute value of negative net income +1 (or zero if the bank earns a profit) to avoid taking the log of zero. Relative profits are based on return on equity. Dividend volatility is the standard deviation of dividend payments in USD over eight quarters preceding the turnover. Type I error denotes the false classification of no turnover as turnover (false positive) and Type II error denotes the false classification of an actual turnover as no turnover (false negative). Robust $z$ statistics in parentheses. All explanatory variables are lagged by one period. ${ }^{* *} p<0.01,{ }^{* *} p<0.05,{ }^{*} p<0.1$. 
We consider the effect of ownership structure in Column 4. While Call Reports provide little information on executive ownership for privately held banks and offer no data to test for the effect of large blockholders, we try to capture whether a bank is closely held by including a dummy variable that takes on the value one if the bank is an S-Corporation (see footnote 20). ${ }^{30}$ There are two reasons for this approach. First, in closely held banks the owners have a strong incentive to directly monitor the executives (DeYoung, Spong, and Sullivan, 2001). Second, the initial owner can distribute ownership rights among a small number of large shareholders to create a coalition among those large shareholders. Such a dilution of power among a limited number of large shareholders enables the initial owner to retain de facto control of the firm (Bennedsen and Wolfenzon, 2000). The dummy variable for S-Corporations remains insignificant and leaves the other key findings qualitatively unchanged.

Column 5 is a robustness check that employs a maximum of eight matched banks instead of the four matches used in the main regressions. The results remain identical. We have also tried two matches, and six matches, with no difference to the main results (not reported).

To adjust for any possible effects of outliers of the risk measure, we winsorize the Z-Score at the $0.5^{\text {th }}$ and the $99.5^{\text {th }}$ percentile in Column 6 . In this regression, we also replace our loss variable with a variable that records losses of the previous 4 periods to allow more time for stakeholders to respond to losses. Our results are not affected in these tests.

In Column 7, we use an ordered logit model. We observe a maximum turnover of three positions simultaneously, and construct the nodes by summing across the different roles of the executives, e.g., president, chairperson, $\mathrm{CEO}, \mathrm{CFO}$, and COO. We consider an instance in which three departures are observed simultaneously as the strongest manifestation of discipline, followed by two departures, and so on. Thus, the rationale underlying our approach is that the disciplining effect is most prominently illustrated if three executives are dismissed. The finding in Column 7 fully reinforces our conjecture, and the Z-Score and the other key variables enter with the expected signs at conventional levels of significance.

\footnotetext{
${ }^{30}$ Note that information about bank executives' shareholdings, including compensation packages, and family relationships among stockholders and executives are contained in the confidential section of the bank examination reports and therefore not available for inclusion in our analysis (see also DeYoung, Spong, and Sullivan, 2001).
} 


\section{REFERENCES}

Adams, R. and H. Mehran, 2003, "Is corporate governance different for bank holding companies?” Federal Reserve Bank of New York Economic Policy Review, April 2003, pp. 123-142.

Ashcraft, A. B., 2008, "Does the market discipline banks? New evidence from regulatory capital mix." Journal of Financial Intermediation, Vol. 17, pp. 543-561.

Basel Committee on Banking Supervision, 2004, "Basel II: International Convergence of Capital Measurement and Capital Standards: a Revised Framework.” June, Bank of International Settlements.

Barro J., and R. Barro, 1990, "Pay, performance, and turnover of bank CEOs." Journal of Labor Economics, Vol. 8, pp. 448-481.

Bennedsen, M., and D. Wolfenzon, 2000, "The balance of power in closely held corporations." Journal of Financial Economics, Vol. 58, pp. 113-139.

Bennedsen, M., F. Perez-Gonzales, and Dolfenzon, 2006, “Do CEOs matter?” NYU Working Paper No. FIN-06-032, Stern School of Business, New York University.

Benston, G.J., and G.G. Kaufman, 1994, "The Intellectual History of the Federal Deposit Insurance Corporation Improvement Act of 1991.” in G. G. Kaufman, ed., Reforming Financial Institutions and Markets in the United States (Boston: Kluwer).

Berger, A., S. Davies, and M. Flannery, 2000, “Comparing market and regulatory assessments of bank performance: Who knows what when?" Journal of Money, Credit and Banking, Vol. 32, pp. 641-667.

Bernanke, B. S., 2009, "Financial Reform to Address Systemic Risk", Speech at the Council on Foreign Relations, March 10, 2009.

Bessler, W., and T. Nohel, 2000, "Asymmetric information, dividend reductions, and contagion effects in bank stock returns." Journal of Banking and Finance, Vol. 24, pp.1831-1848.

Bessler, W., and T. Nohel, 1996, "The stock-market reaction to dividend cuts and omissions by commercial banks." Journal of Banking and Finance, Vol. 20, pp. 1485-1508.

Billett, M., J. A. Garfinkel, and S. O’Neal, 1998, “The cost of market versus regulatory discipline in banking." Journal of Financial Economics, Vol. 48, pp. 333-58.

Bliss, R. R., 2001, "Market discipline and subordinated debt: A review of some salient issues." Federal Reserve Bank of Chicago Economic Perspectives, First Quarter 2001, pp.42-45.

Board of Governors of the Federal Reserve System, 1999, "Using subordinated debt as an instrument of market discipline." Staff Study 172, December. 
Boot, A. W. A., and A. Schmeits, 2000, "Market discipline and incentive problems in conglomerate firms with applications to banking." Journal of Financial Intermediation, Vol. 9, pp. 240-273.

Borokhovich, K. A., R. Parrino, and T. Trapani, 1996, "Outside directors and CEO selection." Journal of Financial and Quantitative Analysis, Vol. 31, pp. 337-355.

Bottazzi, L., M. Da Rin, and T. Hellmann, 2008, "Who are the active investors? Evidence from venture capital.” Journal of Financial Economics, Vol. 89, pp. 488-512.

Bottazzi, L, and M. Da Rin, 2002, "Venture capital and the financing of innovative firms." Economic Policy, Vol. 34, pp. 229-269.

Calomiris, C., 1999, "Building an incentive-compatible safety net." Journal of Banking and Finance, Vol. 23, pp. 1499-1519.

Cannella, A. A., D. R. Fraser, and D. Scott Lee, 1995, "Firm failure and managerial labor markets: Evidence from Texas banking." Journal of Financial Economics, Vol. 38, pp.185-210.

Chen, M. A., 2004, "Executive option repricing, incentives, and retention.” Journal of Finance, Vol. 59, pp. 1167-1199.

Cihak, M., 2007, "Systemic Loss: A measure of financial stability.” Czech Journal of Economics and Finance, Vol. 57, pp. 5-26.

Clayton, M. C., J. C. Hartzell, and J. Rosenberg, 2005, "The impact of CEO turnover on equity volatility." Journal of Business, Vol. 78, pp. 1779-1807.

Covitz, D.M., D. Hancock, and M. Kwast, 2004, “A reconsideration of the risk sensitivity of U.S. banking organization subordinated debt spreads: A sample selection approach" Federal Reserve Bank of New York Economic Policy Review, Vol. 10, pp. 73-92.

Coughlan, A., Schmidt, 1984, "Executive compensation, management turnover, and firm performance." Journal of Accounting and Economics, Vol. 7, pp. 43-66.

Dehejia, R. H., and S. Wahba, 2002, "Propensity score-matching methods for nonexperimental causal studies." Review of Economics and Statistics, Vol. 84, pp.151-161.

De Fond, M., and C. Park, 1999, "The effect of competition on CEO turnover." Journal of Accounting and Economics, Vol. 27, pp. 35-56.

Demirgüç-Kunt, A., E. Detragiache, and T. Tressel, 2008, "Banking on the principles. Compliance with Basel Core Principles and bank soundness." Journal of Financial Intermediation, Vol. 17, pp. 511-42. 
Denis, D. J., D. K. Denis, and A. Sarin, 1997, "Ownership structure and top executive turnover." Journal of Financial Economics, Vol. 45, pp. 193-221.

Denis, D. J., and J. M. Serrano, 1996, “Active investors and management turnover following unsuccessful control contests." Journal of Financial Economics, Vol. 40, pp. 239-66.

DeYoung, R., K. Spong, and R. J. Sullivan, 2001, "Who's minding the store? Motivating and monitoring hired managers at small, closely held commercial banks.” Journal of Banking and Finance, Vol. 25, pp. 1209-1243.

Evanoff, D. D. and Wall, L. D., 2001, “Sub-debt yield spreads as bank risk measures.” Journal of Financial Services Research, Vol. 20, pp. 121-45.

Evanoff, D. D. and Wall, L. D., 2000, “Subordinated debt and bank capital reform.” FRB Chicago Working Paper 2000/07.

Farrell, K. A., and D. A. Whidbee, 2000, "The consequences of forced CEO succession for outside directors." Journal of Business, Vol. 73, pp. 597-627.

Flannery, M., 1998, "Using market information in prudential bank supervision: A review of the U.S. empirical evidence.” Journal of Money, Credit, and Banking, Vol. 30, pp. 273-305.

Flannery, M., 2001, “The 'faces' of market discipline.” Journal of Financial Services Research, Vol. 20, pp. 107-119.

Flannery, M., 2008, “The subprime crisis: Lessons about market discipline.” Mimeo. University of Florida, Gainesville.

Flannery, M.J., and S.M. Sorescu, 1996, "Evidence of bank market discipline in subordinated debenture yields," Journal of Finance, Vol. 51, pp. 1347-77.

Goldberg, L.G., and S. C. Hudgins, 2002, "Depositor discipline and changing strategies for regulating thrift institutions.” Journal of Financial Economics, Vol. 63, pp. 263-274.

Goyal, V. K., 2005, "Market discipline of bank risk: Evidence from subordinated debt contracts.” Journal of Financial Intermediation, Vol. 14, pp. 318-350.

Gropp, R., J. Vesala, and G. Vulpes, 2004, "Market indicators, bank fragility, and indirect market discipline.” Economic Policy Review, Federal Reserve Bank of New York, September Issue, pp. 53-62.

Grossman, S. J. and O. Hart, 1980, "Takeover bids, the free-rider problem, and the theory of the corporation." Bell Journal of Economics, Vol. 11, pp. 42-64.

Hadlock, Charles J., and G. B. Lumer, 1997, “Compensation, turnover, and top management incentives: Historical evidence." Journal of Business, Vol. 70, pp. 153-187. 
Hancock, D., and M. Kwast, 2001, "Using bond and stock markets to monitor bank holding companies." Journal of Financial Services Research, Vol. 20, pp 147-87.

Harford, J. and K. Li, 2007, "Decoupling CEO wealth and firm performance: The case of acquiring CEOs.” Journal of Finance, Vol. 62, pp. 917-49.

Houston, J., and James, C., 1995, “CEO compensation and bank risk: Is compensation in banking structured to promote risk taking?" Journal of Monetary Economics, Vol. 36, pp. 405-31.

Hubbard G, Palia D., 1995, "Executive pay and performance: evidence from the U.S. banking industry." Journal of Financial Economics, Vol. 39, pp. 105-30.

Huson M., P. Malatesta P, and R. Parrino, 2004, "Managerial succession and firm performance." Journal of Financial Economics, Vol. 74, pp. 237-275.

Jensen, M. C., 1988, “Takeovers: Their causes and consequences.” Journal of Economic Perspectives, Vol. 2, pp. 22-48.

Keeley, M. C., 1990, “Deposit insurance, risk, and market power in banking.” American Economic Review, Vol. 80, pp. 1183-200.

Kini, O., W. Kracaw, and S. Mian, 2004, “The nature of discipline by corporate takeovers." Journal of Finance, Vol. 59, pp. 1511-52.

Maechler, A. M., and K. McDill, 2006, “Dynamic depositor discipline in US banks.” Journal of Banking and Finance, Vol. 30, pp. 1871-91.

Martinez Peria, M. S., and S. Schmukler, 2001, "Do depositors punish banks for bad behavior? Market discipline, deposit insurance, and banking crises." Journal of Finance, Vol. 56, pp. 1029-1051.

Mercieca, S., K. Schaeck, and S. Wolfe, 2007, "Small banks in Europe: Benefits from diversification?" Journal of Banking and Finance, Vol. 31, pp. 1975-98.

Morgan, D. P., and K. Stiroh, 2001, "Market discipline of banks: The asset test.” Journal of Financial Services Research, Vol. 20, pp. 195-208.

Nier, E., and U. Baumann, 2006, "Market discipline, disclosure and moral hazard in banking." Journal of Financial Intermediation, Vol. 15, pp. 332-361.

Park, S., and S. Peristiani, 1998, "Market discipline by thrift depositors." Journal of Money, Credit, and Banking, Vol. 30, pp. 347-364.

Parrino, R., R. W. Sias, and L. T. Starks, 2003, "Voting with their feet: Institutional ownership changes around forced CEO turnover." Journal of Financial Economics, Vol. 68, pp. 346. 
Renneboog, L., 2000, "Ownership, managerial control and the governance of companies listed on the Brussels stock exchange." Journal of Banking and Finance, Vol. 24, pp.1959-95.

Rosenbaum, P. R., and D. B. Rubin,, 1983, "The central role of the propensity score in observational studies for causal effects." Biometrika, Vol. 70, pp. 41-55.

Schaeck, K., 2008, "Bank liability structure, FDIC loss, and time to failure: A quantile regression approach." Journal of Financial Services Research, Vol. 33, pp. 163-79.

Shadow Financial Regulatory Committee, 2000, "Reforming bank capital regulation." Statement of the Shadow Financial Regulatory Committee Meeting, American Enterprise Institute, Publication \# 16542, Washington, D.C.

Shleifer, A., and R. W. Vishny, 1986, "Large shareholders and corporate control.” Journal of Political Economy, Vol. 94, pp. 461-488.

Sironi, A., 2001, "An analysis of European banks' SND issues and its implications." Journal of Financial Services Research, Vol. 20, pp. 233-66.

Stern, Gary H. and Ron J. Feldman, 2004, Too Big To Fail: The Hazards of Bank Bailouts, (Washington: Brookings Institution).

Stiroh, K., 2004a, "Do community banks benefit from diversification?" Journal of Financial Services Research, Vol. 25, pp. 135-160.

Stiroh, K., 2004b, "Diversification in banking: Is noninterest income the answer? Journal of Money, Credit, and Banking, Vol. 36, pp. 853-82.

Warner, J., Watts, J., Wruck, K., 1988, Stock prices and top management changes.” Journal of Financial Economics, Vol. 20, pp. 461-92.

Webb, E., 2008, "Regulator scrutiny and bank CEO incentives.” Journal of Financial Services Research, Vol. 33, pp. 5-20.

Weisbach, M., 1988, “Outside directors and CEO turnover." Journal of Financial Economics, Vol. 20, pp. 431-460.

Yafeh, Y., and O. Yosha, 2003, "Large shareholders and banks: Who monitors and how?" Economic Journal, Vol. 113, pp. 128-146. 